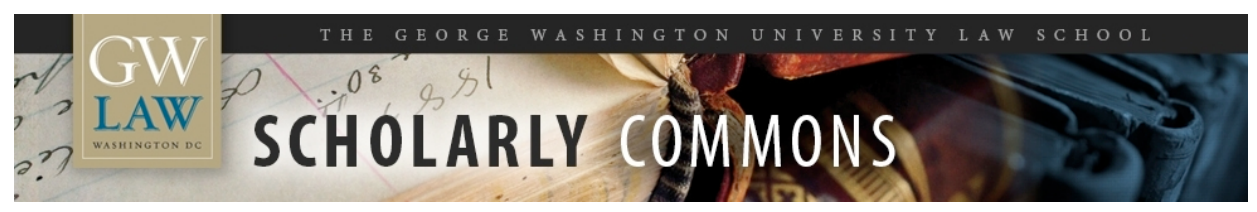

\title{
A Concise Guide to the Federalist Papers as a Source of the Original Meaning of the United States Constitution
}

\author{
Gregory E. Maggs \\ George Washington University Law School, gmaggs@law.gwu.edu
}

Follow this and additional works at: https://scholarship.law.gwu.edu/faculty_publications

Part of the Law Commons

\section{Recommended Citation}

Gregory E. Maggs, A Concise Guide to the Federalist Papers as a Source of the Original Meaning of the United States Constitution, 87 B.U. L. Rev. 801 (2007).

This Article is brought to you for free and open access by the Faculty Scholarship at Scholarly Commons. It has been accepted for inclusion in GW Law Faculty Publications \& Other Works by an authorized administrator of Scholarly Commons. For more information, please contact spagel@law.gwu.edu. 


\title{
A Concise Guide To The Federalist Papers As A Source Of The Original Meaning OF THE UNiTED STATES CONSTITUTION
}

\author{
Gregory E. Maggs*
}

\section{INTRODUCTION}

The Constitutional Convention approved the text of the Constitution on September 17, 1787. But the Constitution, by its own terms, could not go into effect until nine states had ratified it. ${ }^{1}$ In the fall of 1787 and spring of 1788, Alexander Hamilton, James Madison, and John Jay undertook efforts to help make this happen. Working together, they wrote a series of 85 essays explaining the Constitution and urging its ratification in the State of New York. Each of these essays bore the title "The Federalist" followed by a number designating its order in the series. Historians typically refer to the 85 essays as the "Federalist Papers."

\footnotetext{
* Professor of Law, George Washington University Law School. This is one of a series of guides to important sources of the original meaning of the U.S. Constitution that I am writing. Other guides, now in progress but not yet published, will address the Declaration of Independence, the Articles of Confederation, the notes from the Constitutional Convention, the early acts of Congress, early judicial decisions, and other sources commonly cited as evidence of the original meaning of the Constitution. I would like to thank Professors Bradford Clark, Peter Smith, and Arthur Wilmarth for their comments and suggestions. The George Washington University Law School has provided me with generous financial support.

${ }^{1}$ U.S. Const. art. VII ("The ratification of the conventions of nine states, shall be sufficient for the establishment of this Constitution between the states so ratifying the same.").

${ }^{2}$ Some writers also refer to the collection of the essays simply as "The Federalist." I have avoided this usage because it can be confusing. As described below, Hamilton, Madison, and Jay originally published most of the essays in newspapers. See infra part III. Hamilton also collected these essays in a two-volume book called The Federalist: A Collection of Essays Written in Favour of the New Constitution, As Agreed Upon by the Federal Convention, September 17, 1787 (1788). In editing this work, Madison edited the essays and he added new ones that had not appeared in newspapers. See infra part III.
} 
The Federalist Papers long have enjoyed a special reputation as an extremely important source of evidence of the original meaning of the Constitution. In 1821, in Cohens v. Virginia, Chief Justice John Marshall described the collection of essays in the following glowing terms:

It is a complete commentary on our constitution; and is appealed to by all parties in the questions to which that instrument has given birth. Its intrinsic merit entitles it to this high rank; and the part two of its authors [i.e., Hamilton and Madison] performed in framing the constitution, put it very much in their power to explain the views with which it was framed. ${ }^{3}$

The serious attention given to the Federalist Papers has not waned, but instead has grown, since Chief Justice Marshall wrote these words. In the aggregate, academic writers and jurists have cited the Federalist Papers as evidence of the original meaning of the Constitution more than any other historical source except the text of the Constitution itself. My own computer searches have revealed that more than 9700 law review articles and more than 1700 cases have referred to the essays. ${ }^{4}$ The Supreme Court takes the essays especially seriously. It recently quoted the Federalist $\mathrm{Pa}-$ pers 35 times in a single case, Printz $v$. United States. ${ }^{5}$ As a result, almost anyone interested in constitutional law needs to be familiar with the Federalist Papers. (This includes both readers who believe that the original meaning of the Constitution should influence the courts, and those who do not - a subject I address later.)

But many lawyers, judges, law clerks, and legal scholars do not feel remotely prepared to make or evaluate claims about the original meaning of the Constitution based on the Federalist Papers. The typical law school curriculum acknowledges the importance of the Federalist Papersusually by assigning Supreme Court cases which cite them-but does not treat the essays in depth. As a result, many law students and graduates still need accessible information about the creation, content, and distribution of the essays, manageable summaries of the theories under which the

I prefer to use the term "Federalist Papers" to encompass both what appeared in newspapers and what appeared in the two-volume collection.

319 U.S. (6 Wheat.) 264, 418 (1821) (Marshall, C.J.).

"I searched for "Federalist No." in Westlaw's JLR and ALLCASES databases.

521 U.S. 898 (1997). 
Federalist Papers might provide evidence of the original meaning, and instruction on possible grounds for impeaching claims about the original meaning based on the Federalist Papers.

I seek to address these needs in this guide to the Federalist Papers. The guide provides the essential background that lawyers, judges, law clerks, and legal scholars ought to have before advancing, contesting, or evaluating claims about the original meaning of the Constitution based on the Federalist Papers. I have tried to keep the guide concise so that the intended audience will have time to read it. At the same time, I hope that the guide is sufficiently analytical to promote critical thinking, careful judgment, and judicious evaluation of arguments that rely on the Federalist Papers.

In part II, I address the significant initial question of what the term "original meaning" embraces. I show that legal writers use this generic term to cover three different kinds of historic meaning. They include the original intent of the Framers of the Constitution, the original understanding of the persons who participated in the ratification of the Constitution at the Constitutional Convention, and the original objective meaning of the Constitution's text. Understanding the distinctions among these three types of meaning is important because the Federalist Papers do not provide equal evidence of each of them. (I do not give any one of the three preference in this guide, but instead consider each of them.)

In part III, I describe the Federalist Papers. I explain who wrote them, what they are about, where they were published, why they were written, and how they were distributed. The basic facts are perhaps more complicated than many might at first imagine. And some of the details are surprising and interesting - like the existence of two versions of the Federalist Papers (each having its own text and numbering system), the very small circulation of the essays in 1787 and 1788, and the absence of any explicit reference to the essays in the records of the state ratifying conventions.

In part IV, I address the theoretical grounds for believing that the Federalist Papers might provide evidence of the original meaning (including the original intent, original understanding, and original objective meaning). To make the discussion concrete, I have included multiple examples from judicial opinions and scholarly articles. In addition, I briefly discuss 
one possible ground for citing the Federalist Papers in connection with constitutional arguments other than as proof of the original meaning.

In part V, I address nine arguments often used for impeaching claims about the original meaning based on the Federalist Papers. These arguments are very important. Almost as a general rule, whenever an author cites the Federalist Papers to establish the original meaning, some critics respond that the essays do not support the author's conclusion. Common objections that the critics raise include the following:

1. Delegates to the state ratifying conventions could not or did not read many of the Federalist Papers.

2. The Federalist Papers may not have been persuasive to the ratifiers.

3. The Federalist Papers are often self-contradictory.

4. Hamilton and Jay are not ideal expositors of the original intent of the Framers.

5. The secrecy of the Constitutional Convention makes the Federalist Papers an unreliable source of evidence of the original intent of the Framers.

6. Statements in the Federalist Papers often conflict with other sources.

7. The Federalist Papers provide questionable evidence of the original objective meaning of the Constitution because partisan bias may have influenced the authors' choice of words and phrases.

8. The Federalist Papers were not treated as an authoritative exposition of the meaning of the Constitution in the early years of the Republic.

9. The Federalist Papers were not written to provide a definitive interpretation of the Constitution, but instead to address the question of whether the Constitution should be adopted.

Each of these nine arguments has some merit. None of them is a straw man; authors writing about the Federalist Papers have strenuously advanced each of them at one time or another. But at the same time none of the arguments is so overwhelmingly strong that it should prevent any reliance on the Federalist Papers. On the contrary, all of the arguments are all subject to significant counterarguments. That is why authors continue to cite the Federalist Papers, and why critics continue to argue about what the 
citations prove. My recommendation is simply this: Any person making or evaluating a claim about the original meaning should take these nine arguments into account, and anyone using these arguments to impeach claims about the original meaning should consider carefully the counterarguments. Following these recommendations will strengthen any debate, even if it will not finally resolve all controversies regarding the Federalist Papers.

In part VI, I state a brief conclusion. This conclusion is followed by two appendices. Appendix A recommends sources for the text of the Federalist Papers and further information about the history of their creation. Appendix B lists the chronology of the publication of the essays and the drafting and ratification of the Constitution.

Before going further, one important point requires explicit recognition: Attorneys have a notorious reputation for being poor historians. Although this article counts lawyers, judges, law clerks, and legal scholars among its intended audience, it cannot and does not seek to make them experts of American history. Indeed, it is not even written by a historian. Although I have studied and taught constitutional law for many years, I cannot claim anything but a lawyer's knowledge of the founding period. My goal is only to provide a usable guide to a source generally seen as relevant to determining the original meaning of the nation's most fundamental legal document.

\section{Definitions of "Original Meaning"}

Before addressing the Federalist Papers themselves, an essential initial question is: What does the phrase "original meaning" of the Constitution embrace? This question does not have any single answer. On the contrary, judges and legal scholars attempting to discern the original meaning of the Constitution have recognized that at least three different kinds of original meaning may have existed. Anyone writing or reading about the Federalist Papers should recognize and think carefully about the distinctions among these meanings.

One kind of original meaning, which I will call the "original intent," is

the meaning that the Framers of the Constitution - the delegates who drafted the document in 1787 -intended the Constitution to have. It is 
what the Supreme Court as early as 1838 called the "meaning and intention of the convention which framed and proposed [the Constitution] for adoption and ratification to the conventions of the people of and in the several states." When historians attempt to discern the original intent, they seek to discover what the delegates at the Constitutional Convention actually thought the Constitution meant, not what reasonable persons should have thought or what the ratifiers of the Constitution later actually did think. Evidence of the original intent may take many forms. But the classic method of determining the original intent is to look at what the Framers said about the Constitution during debates at the Constitutional Convention. ${ }^{7}$

A second kind of original meaning, which I will call the "original understanding," refers to what the persons who participated in the state ratifying conventions thought that the Constitution meant. ${ }^{8}$ This original understanding may differ somewhat from the original intent for a simple reason: The Constitutional Convention met in secret and its records did not become public until many years after ratification of the Constitution. ${ }^{9}$ As a result, the ratifiers - except for the few who had participated in the Constitutional Convention-could not know exactly what the framers intended. As a result, the ratifiers may have attached to the Constitution meanings different from those intended by the framers. For example, consider the federal treaty power. Notes taken at the Constitutional Convention suggest that some of the framers intended that treaties normally would be self-executing (i.e., that they would not require implementing legisla-

\footnotetext{
${ }^{6}$ Rhode Island v. Massachusetts, 37 U.S. (12 Pet. 657) 657, 721 (1838).

7 See, e.g., U.S. Term Limits, Inc. v. Thornton, 514 U.S. 779, 809 (1995) (quoting comments of James Madison at the Constitutional Convention as evidence of the original intent of the framers); id. at 860 (1995) (Thomas, J., dissenting) (same).

${ }^{8}$ See Alden v. Maine, 527 U.S. 706, 707, 726-27 (1999) (discussing evidence of the "original understanding" of the ratifiers of the Constitution).

9 Max Farrand's classic RECORDS OF THE FEDERAL CONVENTION OF 1787 (rev. ed. 1937) (4 volumes) contains all the notes and records of the Constitutional Convention known as of 1937. The introduction contains an extremely detailed account of who took the notes, when they were published, and why they may have inaccuracies.
} 
tion), but records from the state ratifying conventions indicate that some of the ratifiers of the Constitution had exactly the opposite understanding. ${ }^{10}$

A third kind of original meaning, which I call the "original objective meaning" (and which is also known as the "original public meaning"), is the reasonable meaning of the text of the Constitution at the time of the framing. ${ }^{11}$ This meaning is not what Hamilton, Madison, or the other framers subjectively intended, not what the numerous participants at the ratification debates actually understood, but instead what a reasonable person of the era would have thought. It is a hypothetical meaning that someone reading the Constitution in 1787-1788 might have understood the document to mean. Justice Antonin Scalia tends to consider this meaning the most significant. He has written: "What I look for in the Constitution is precisely what I look for in a statute: the original meaning of the text, not what the original draftsmen intended."12 The standard way of discerning this objective meaning is to look at a variety of writings from the founding period to discern the customary meaning of words and phrases in the Constitution. ${ }^{13}$

Writers have debated extensively the question of which of these kinds of original meaning has the greatest legal significance. Some assert that the original understanding is more important than the original intent. ${ }^{14}$ Others argue that the original objective meaning is the most important. ${ }^{15}$ The issue has considerable importance because, as explained above, the

\footnotetext{
${ }^{10}$ See John Yoo, Globalism and the Constitution: Treaties, Non-self-execution, and the Original Understanding, 99 COLUM. L. REV. 1955, 2037-38, 2074 (1999) (summarizing conflicting views at the Constitutional Convention and the state ratifying convention).

${ }^{11}$ See RANDY E. BARNETT, RESTORING THE Lost CONSTITUTION 100-09 (2004) (describing this kind of meaning).

12 Antonin Scalia, Common-Law Courts in a Civil-Law System: The Role of United States Federal Courts in Interpreting the Constitution and Laws, in A MATTER OF INTERPRETATION 38 (Antonin Scalia \& Amy Gutmann, eds., 1998).

${ }^{13}$ See, e.g., Randy E. Barnett, The Original Meaning of the Commerce Clause, $68 \mathrm{U}$. CHI. L. REV. 101, 111-112 (2001) (using the methodology to determine whether the word "commerce" in the Commerce Clause refers specifically to the exchange of goods or more broadly to any gainful activity).

${ }^{14}$ See, e.g., Ronald D. Rotunda, Original Intent, the View of the Framers, and the Role of the Ratifiers, 41 VAND. L. REV. 507, 512 (1980).

${ }^{15}$ See, e.g., Gary Lawson, Delegation and Original Meaning, 88 VA. L. REV. 327, 398 (2001).
} 
three kinds of original meaning conceivably could differ from each other. But I do not address this question here. Rather, I consider separately all three different possible kinds of original meaning on grounds that some users of this guide may be interested in all of them.

A related question is: Why does the original meaning of the Constitution matter? Certainly readers will have differing opinions on the question of whether or when courts must follow the original meaning of the Constitution. ${ }^{16}$ Let me say only that I also do not address the debate in this article. Instead, I simply assume that anyone looking at this guide either wants to cite the Federalist Papers as a source of the original meaning of the Constitution or needs to assess or respond to someone else's citation of the Federalist Papers. For that they need to know details about the essays, the theories for citing them, and the grounds for impeaching claims based on them, even if they disagree about the extent to which the original meaning of the Constitution binds the courts.

\section{The Creation and Publication of the Federalist Papers}

\section{Purpose and Intended Audience}

In a letter written late in his life, James Madison succinctly explained the purpose of the Federalist Papers: "The immediate object of them was to vindicate and recommend the new Constitution to the State of New York, whose ratification of the instrument was doubtful, as well as important." ${ }^{17}$ In accordance with this purpose, Hamilton, Madison, and Jay addressed each of the essays "To the People of the State of New York."

\footnotetext{
${ }^{16}$ For classic defenses of originalism - the school of constitutional interpretation that courts must follow the original meaning of the Constitution-see generally RAOUL BERger, GOVERnMENT BY JUdiciary (1977); Antonin Scalia, Originalism: The Lesser Evil, 57 U. CIN. L. Rev. 849 (1989); RoBert H. BorK, THE TEMPTING OF AMERICA: THE Political SEDUCTION OF THE LAW (1990); Lino A. Graglia, Constitutional Interpretation, 44 SYRACUSE L. REV. 631 (1993). For classic criticism of originalism, see Paul Brest, The Misconceived Quest for the Original Understanding, 60 B.U. L. REV. 204 (1980); Jefferson Powell, The Original Understanding of Original Intent, 98 HARV. L. REV. 885 (1985); Boris Bittker, The Bicentennial of the Jurisprudence of Original Intent: The Recent Past, 77 CALIF. L. REV. 235 (1989).

${ }^{17}$ Letter from James Madison to James K. Paulding (July 24, 1818), in 8 THE WRITINGS OF JAMES MADISON 410 (Galliard Hunt ed., 1908).
} 
They began writing the 85 essays in October 1787, just three weeks after the Constitutional Convention had ended, and they finished writing them in May 1788, shortly before the New York state ratifying convention. ${ }^{18}$

Hamilton, Madison, and Jay had good reason for doubting whether New York would support ratification. New York's delegation to the Constitutional Convention in Philadelphia had not approved the proposed Constitution. ${ }^{19}$ Two of New York's deputies, John Lansing Jr. and Robert Yates, left Philadelphia in July 1787-during the middle of the Convention-because they believed that the Convention improperly had departed from the goal of merely amending the Articles of Confederation. ${ }^{20}$ Although Alexander Hamilton remained in Philadelphia, he could not represent New York without the presence of Lansing and Yates. ${ }^{21}$

In addition, in the weeks that followed the Constitutional Convention, New York City newspapers published various essays opposing the Constitution. These essays included objections by New York governor George Clinton, who later became the president of the state ratifying convention. ${ }^{22}$ The opposition to ratification continued in the ensuing months. In April

${ }^{18}$ The chronology in Appendix B infra shows the date of first publication of each of the 85 essays. More information about their publication appears below.

19 Article VII says that the Constitution received the "Unanimous Consent of the States" present at the Convention, but it slyly does not mention that New York was not present when the Constitution was signed. U.S. Const. art. VII. See also 2 FARRAND, supra note 9, at 665 (record identifying the states present when the Constitutional Convention approved the Constitution). Indeed, the Constitution may have given casual readers the impression that New York's delegation was present and had consented. Article VII carefully identifies the persons who signed the constitution not as deputies in support of the Constitution, but instead as witnesses. Alexander Hamilton accordingly was able to sign the Constitution, with an indication that he was from New York, because he was only witnessing that the Constitution had the unanimous consent of the states present.

${ }^{20}$ See 3 FARRAND, supra note 9, at 244-47 (letter from Robert Yates and John Lansing, Jr. to the Governor of New York explaining why they left the Convention).

${ }^{21}$ The Convention had adopted a rule permitting a state to vote only when "fully represented." See 1 FARRAND, supra note 9, at 8 (Journal, May 28, 1787). This rule prevented Hamilton from voting on behalf of New York, but did not prevent him from speaking and otherwise participating.

${ }^{22}$ Governor Clinton apparently wrote under the pseudonym "Cato." For his letters, see Cato to Citizens of New York (Sept. 1787-Jan. 1788), in 2 ThE COMPLETE ANTIFEDERALIST 101-117 (Herbert J. Storing ed., 1981). 
1788, when New York elected 65 delegates to its ratifying convention, ${ }^{23}$ only 19 (including Hamilton and Jay) initially supported ratification. ${ }^{24}$

Hamilton, Madison, and Jay also had grounds for thinking that ratification in New York was important. ${ }^{25}$ New York was a populous state. ${ }^{26}$ It occupied a large geographical area in the middle of the proposed Republic. New York City already had become the most important center of commerce in the United States. The new union proposed by the Constitution might not have succeeded if New York had decided not to join.

\section{Authors}

Alexander Hamilton was a leading New York attorney and politician. He previously had written highly regarded essays in support of the Revolution and, during the war, he had served as George Washington's aide-decamp. ${ }^{27}$ Hamilton represented New York in the Congress under the Articles of Confederation and had served as a deputy from New York at the Constitutional Convention in $1787 .{ }^{28}$ Although Hamilton had wanted to create a stronger federal government, he supported the Constitution's ratification as a clear improvement over the Articles of Confederation. While writing his contributions to the Federalist Papers during 1787 and 1788, Hamilton was practicing law in New York and representing New York in Congress. In April of 1788, Hamilton was elected to serve as a delegate to the New York state ratifying convention, where he played a prominent

232 Jonathan Elliot, The Debates in the SeVeral State Conventions on the AdOPTION OF THE FEDERAL CONSTITUTION 206-208 (1836) [hereinafter ElliotT'S DEBATES] (listing delegates).

${ }^{24}$ See Norman R. Williams, The Failings of Originalism: the Federal Courts and the Power of Precedent, 37 U.C. DAVIS L. REV. 761, 811 \& n.192 (2004).

${ }^{25}$ The Constitution technically did not require New York's ratification to go into effect. On the contrary, Article VII said that ratification of any nine states could establish the Constitution "between the states so ratifying." U.S. Const. art. VII. Thus, the United States in theory could have existed without New York's ratification. In fact, the new government began before Rhode Island ratified the Constitution.

${ }^{26}$ The 1790 census counted 340,241 persons in New York, making it smaller in population only than Massachusetts, North Carolina, Pennsylvania, and Virginia.

27 See Richard BroOKHISER, AlEXANDER HAMILTON: AMERICAN 24-25, 29 (2000).

${ }^{28}$ See id. at 51,62 . 
role in securing the State's approval of the Constitution. ${ }^{29}$ Hamilton later became the Secretary of Treasury. ${ }^{30}$

John Jay was also an extremely important state and national figure. He had been a revolutionary leader, President of Congress under the Articles of Confederation, and the United States Minister to Spain. ${ }^{31}$ He had helped to draft the New York state constitution, he was the Chief Justice of New York, and along with Benjamin Franklin he had negotiated the peace treaty with Great Britain at the end of the Revolutionary War. ${ }^{32} \mathrm{He}$ had not participated in the Constitutional Convention because he was occupied as the Secretary for Foreign Affairs for the United States. ${ }^{33}$ Jay, like Hamilton, also was a delegate to the New York state ratifying convention. ${ }^{34}$ He later served as Chief Justice of the United States and as the governor of New York. ${ }^{35}$

Hamilton apparently asked Gouverneur Morris of Pennsylvania to help with the Federalist Papers. ${ }^{36}$ Morris was a great writer and, as a delegate to the Constitutional Convention, he had put much of the Constitution's grand language in its final form. But Morris declined to assist them. They also may have asked William Duer, the secretary of the United States Board of Treasury, to join them in the project. ${ }^{37}$ Duer ultimately wrote a few essays in support of the Constitution, but he did not make them part of the Federalist series. ${ }^{38}$

Hamilton and Jay then turned to James Madison. Madison had represented Virginia in the Continental Congress and previously had served in

\footnotetext{
${ }^{29}$ See id. at 73-76.

${ }^{30}$ See id. at 77.

${ }^{31}$ See George Pellew, John Jay 59, 105, 120 (1890).

${ }^{32}$ See id. at 77, 166, 197.

${ }^{33}$ See id. at 229.

${ }^{34}$ See id. at 255.

${ }^{35}$ See id. at 294, 318.

${ }^{36}$ See Douglass Adair, The Authorship of the Disputed Federalist Papers: Part II, 1 WM. \& MARY QUARTERLY 235, 245 (1944).

${ }^{37}$ See James Madison, Memorandum Entitled "The Federalist" (circa 1819), in 4 THE PAPERS OF ALEXANDER HAMILTON 288 (Harold C. Syrett \& Jacob E. Cooke eds., 1962) [hereinafter Madison's Memorandum].

${ }^{38}$ See FriendD OF THE CONSTITUTION: WRITINGS OF THE "OTHER" FEDERALISTS 17871788 at 111 (Colleen A. Sheehan \& Gary L. McDowell eds., 1998) (William Duer writing as "Philo-Publius").
} 
the Virginia Assembly. ${ }^{39}$ Madison had played a key role at the Constitutional Convention. He had drafted the "Virginia Plan" that became the Constitution's foundation and had made numerous influential speeches. ${ }^{40}$ Although Madison was from Virginia, rather than New York, geography did not pose an obstacle to his participation in writing the Federalist Papers. During 1787 and 1788, Congress under the Articles of Confederation was meeting in New York City, and Madison was there representing Virginia. ${ }^{41}$ Madison served as a delegate to the Virginia state ratifying convention where he, like Hamilton and Jay in New York, actively and successfully supported approval of the Constitution. ${ }^{42}$ He later became a member of Congress, where he proposed the Bill of Rights as an Amendment to the Constitution. ${ }^{43}$ And he subsequently served as Secretary of State and President of the United States. ${ }^{44}$

During 1787 and 1788, the three authors were busy with other obligations and did not have adequate time to research or even discuss the essays that they composed. Madison later explained that most of the essays were written "in great haste, and without any special allotment of the different parts of the subject to the several writers." ${ }^{25}$ The essays, accordingly, contain various errors and repetitive discussions. Madison also acknowledged that, because of "a known difference in the general complexion of their political theories," the three writers wanted to work separately and not necessarily endorse each other's views. ${ }^{46}$

\section{Anonymity}

Hamilton, Madison, and Jay did not sign their names to the Federalist Papers. Instead, they wrote all of them under the pseudonym "PUBLIUS." They chose the name Publius because it was the first name of Publius Valerius Publicola, an important supporter of the Roman Re-

${ }^{39}$ See RAlPh Ketchum, JAMES MADISON: A BIOGRAPHY 89-92, 154 (reprint ed. 1990).

${ }^{40}$ See id. at 196-226.

${ }^{41}$ See id. at $232-233$.

${ }^{42}$ See id. at 231-249.

${ }^{43}$ See id. at $289-92$.

${ }^{44}$ See id. at 406, 466-469.

${ }^{45}$ See Madison's Memorandum, supra note 37, at 288.

${ }^{46} \mathrm{Id}$. 
public. ${ }^{47}$ They apparently saw themselves as analogous proponents of the proposed new federal republic. (William Duer published his separate essays under the pseudonym "Philo-Publius," or friend of Publius. ${ }^{48}$ )

Why the authors thought that signing their own names would have less political advantage than using a pseudonym remains unclear. Perhaps Hamilton and Madison felt that praising a Constitution that they had helped to write would appear immodest. Maybe they wanted to make arguments that they later could distance themselves from. They might have wanted to avoid accusations that they were violating the confidentiality of the Constitutional Convention. Or they could have decided that their group should use just one name to cover the work of all three authors. But whatever their reason, their use of a pseudonym probably did not stand out as unusual; political writers of the time commonly used pseudonyms in essays published in newspapers. As Justice Clarence Thomas has observed, in all of the major essays published in favor of or against the Constitution, only George Mason and Luther Martin signed their true names, and they had a special reason for doing so. ${ }^{49}$ All of the other commonly cited authors wrote anonymously.

Even though Hamilton, Madison, and Jay did not openly claim authorship of the essays, they also did not keep their involvement in the project a complete secret. Historian Jacob E. Cooke has surmised that their friends knew of their participation and that many people in New York suspected that Hamilton was leading the project. ${ }^{50}$ We know that James Madison, Alexander Hamilton, and John Jay revealed some of their role in the letters that they wrote to George Washington, Edmund Randolph, and Tho-

\footnotetext{
${ }^{47}$ See THE FEDERALIST PAPERS x (Clinton Rossiter ed., 1961)

${ }^{48}$ See supra note 38.

49 See McIntyre v. Ohio Elections Com'n, 514 U.S. 334, 368 \& n.3 (1995) (Thomas, J., concurring in the judgment) (citing George Mason, Objections to the Constitution, VIRGINIA JOURNAL (Nov. 22, 1787), reprinted in 1 DEBATE ON THE CONSTITUTION 345 (B. Bailyn ed. 1993), and Luther Martin, The Genuine Information, MARYLAND GAZETTE (Dec. 28, 1787-Feb. 8, 1788), reprinted in 1 FARRAND, supra note 9 at 631). Justice Thomas says that Mason and Martin may have felt that they needed to explain why they attended the Constitutional Convention but did not sign the Constitution. See id.

${ }^{50}$ See The FEDERALIST xviii-xix (Jacob E. Cooke ed., 1961).
} 
mas Jefferson. ${ }^{51}$ In addition, at least two items published in newspapers speculated that Hamilton was writing as Publius. ${ }^{52}$ Still, in 1787 and 1788, most readers of the Federalist Papers would not have known the identity of the authors.

The anonymity of the essays has not prevented historians from deducing how Hamilton, Madison, and Jay divided the work on the project. Based on subsequent statements by the authors and differences in writing style, they now generally agree that Hamilton wrote numbers 1, 6-9, 1113, 15-17, 21-36, 59-61, and 65-85; that Madison wrote numbers 10, 14, 18-20, 37-58, and 62-63; and that Jay wrote numbers 2-5 and $64 .{ }^{53}$ (Illness prevented Jay from contributing as much as Hamilton and Madison.) The three men apparently did not co-author any of the essays.

\section{Publication}

The story of the Federalist Papers' publication is complicated, but the details require careful attention for two reasons. First, the facts regarding publication may affect assumptions about who may have read the essays during the ratification period. Second, slightly different versions of the essays appeared during 1787 and 1788, and the existence of these different versions may cause confusion.

(1) Numbering and Text

Hamilton, Madison, and Jay initially published most of the Federalist Papers in New York City newspapers during the fall of 1787 and the spring of 1788. (The chronology in Appendix B gives the exact dates.) While the essays were still being written and published in the newspapers, Hamilton arranged to have them reprinted in a two-volume book called The Federalist: A Collection of Essays Written in Favour of the New Constitution, As Agreed Upon by the Federal Convention, September 17,

${ }^{51}$ See 13 The Documentary History of the RATIFICATION OF THE CONSTITUTION 489 (John P. Kaminski \& Gespare J. Saladino eds., 1981) (Commentary No. 201) [hereinafter Commentary No. 201].

${ }^{52} \mathrm{Id}$. at 488 .

53 See The Federalist xx-xxi (Jacob E. Cooke ed., 1961). Historians have disputed whether Hamilton or Madison wrote number 15, but most agree that it was Hamilton. See id. 
1787. This work, published by John and Archibald M'Lean (sometimes spelled "McLean"), has become known as the "M'Lean Edition."

The first volume of the M'Lean Edition appeared on March 22, 1788. It reprinted the essays that had been numbered 1 through 35 in the newspapers, subject to four important editorial actions. First, Hamilton tinkered slightly with the order of the essays. The essay that had been number 35 in the newspapers became number 29 in the M'Lean Edition, and the numbering of the subsequent essays all increased because of this change. Second, Hamilton divided the essay that had been numbered 31 in the newspapers into two essays (renumbered as 32 and 33). The first volume of the M'Lean edition thus contained a total of 36 rather than 35 essays. Third, Hamilton slightly edited the text of the essays. Fourth, Hamilton included an unsigned preface, explaining the purpose of the essays and apologizing for their redundancy and hurried writing.

The second volume of the M'Lean Edition was published on May 28, 1788. It included the essays that had been numbered 36 through 76 in the newspapers, and renumbered them 37 through 77 (given that the original essay 31 had been divided). The second volume also included eight new essays that had not previously appeared in the newspapers. These new essays were numbered 78 to 85 . The new essays subsequently were republished in New York City newspapers, which also numbered them 78 to 85. As a result, no essay numbered 77 ever appeared in the newspapers.

Table \#1, based on a very useful explanation by Jacob E. Cooke, ${ }^{54}$ shows the differences in numbering between the newspapers and the M'Lean Edition:

${ }^{54}$ See id.at xviii. 
Table \#1

\section{Comparison of Newspaper Numbering to the M'Lean Edition Numbering}

\begin{tabular}{|l|l|}
\hline $\begin{array}{l}\text { Essay Number in } \\
\text { the Newspapers }\end{array}$ & $\begin{array}{l}\text { Essay Number in the M'Lean } \\
\text { Edition }\end{array}$ \\
\hline $1-28$ & $1-28$ \\
\hline 29 & 30 \\
\hline 30 & 31 \\
\hline 31 & $32 \& 33$ (split into two essays) \\
\hline 32 & 33 \\
\hline 33 & 34 \\
\hline 34 & 36 \\
\hline 35 & 29 \\
\hline $36-76$ & $37-77$ \\
\hline $78 *-85$ & $78-85$ \\
\hline
\end{tabular}

*No essay numbered 77 appeared in the newspapers.

Because the text and numbering of the essays in M'Lean Edition differ from the text and numbering of the essays in the newspapers, questions may arise about what numbering system and what text authors should use when they cite the Federalist Papers. The issue of numbering is easy. Almost all works, both old and modern, use the M'Lean Edition numbering. Researchers long ago settled on the M'Lean Edition numbering because the actual newspapers that published the Federalist Papers were impossible to find outside of a very few libraries. Although reprints of the newspaper versions have now become available, the practice of using the M'Lean Edition numbering has continued. To avoid confusion, I recommend that authors use the M'Lean numbering and explain to their readers that they are doing that. 
The issue of text is more difficult. Almost all older works also cite the M'Lean Edition text. Modern works, however, sometimes rely on the M'Lean Edition text and sometimes rely on the newspaper text. Unfortunately, sources often do not make clear which text they are citing or quoting. But here is a useful guide: The two most commonly cited modern editions of the essays are The Federalist Papers by Clinton Rossiter ${ }^{55}$ and The Federalist by Jacob E. Cooke. ${ }^{56}$ The Rossiter compilation uses the M'Lean edition text, while the Cooke version uses the newspaper text. The Supreme Court in recent years has cited each of these works apparently without giving one more significance than the other. ${ }^{57}$ So probably the text chosen does not matter in most cases. But any citation of the Federalist Papers should indicate its source. ${ }^{58}$

(2) Publication of The M'Lean Edition

John and Archibald M'Lean printed 500 copies of their two-volume collection of the essays. The book initially did not sell very well. The publishers complained in October 1788, long after New York had ratified the Constitution, that they still had several hundred unsold copies. ${ }^{59}$ Some copies of the book, however, did travel far. The M'Leans shipped dozens of copies to locations outside New York City, and Hamilton sent about 50 copies to Richmond in time for the Virginia state ratifying convention. ${ }^{60}$

\footnotetext{
55 See The FEDERALIST PAPERS xxxvi (Clinton Rossiter ed., 1961).

${ }^{56}$ See THE FEDERALIST ix (Jacob E. Cooke ed., 1961).

${ }^{57}$ For recent examples of citations to the Rossiter edition, see, e.g., Roper v. Simmons, 543 U.S. 551, 578 (2005); United States v. Booker, 543 U.S. 220, 239 (2005); Eldred v. Ashcroft 537 U.S. 186, 212 n.18 (2003). For recent examples of citations to the Cooke edition, see, e.g., Sosa v. Alvarez-Machain, 542 U.S. 692, 713 (2004); American Ins. Ass'n v. Garamendi, 539 U.S. 396, 414 (2003); JPMorgan Chase Bank v. Traffic Stream (BVI) Infrastructure Ltd., 536 U.S. 88, 96 (2002).

${ }^{58}$ For citation form, the Bluebook says to "list the usual publication information for the edition cited" and gives the following example: "THE FEDERALIST No. 5, at 53 (John Jay) (Clinton Rossiter ed., 1961)." The BluebooK: A Uniform System OF Citation 114 (18th ed. 2005).

${ }^{59}$ See Allan Maclane, Hamilton: The Intimate Life of AleXander Hamilton 82 (1910).

${ }^{60}$ See Commentary No. 201, supra note 51, at 491-92; THE FEDERALIST PAPERS xi (Clinton Rossiter ed., 1961) ("Copies of the collected edition were rushed to Richmond at Hamilton's direction and used gratefully by advocates of the Constitution in the climactic debate over ratification.").
} 
(3) Publication in New York City newspapers

In 1787 and 1788, New York City had seven newspapers. Four of these newspapers published some or all of the Federalist Papers. ${ }^{61}$ The New York Packet and The Independent Journal, or The General Advertiser (published by the M'Leans) printed the entire collection. The Daily Advertiser printed the essays later numbered 1 through 51 in the M'Lean Edition. The New-York Journal printed the essays later numbered 23 through 39. Publication of the first 76 essays in the newspapers (which would become 77 essays in the M'Lean Edition) took place at a rate of about two essays a week between October 27, 1787 and April 2, 1788. The final eight essays in the Federalist Papers series were reprinted in the New York City newspapers between June 14 and August 16, 1788 only after first appearing in the M'Lean Edition.

Although the exact circulation of these New York City newspapers remains unknown, the average circulation of daily and semi-weekly newspapers at the end of the 18th century was probably at most about 600 to 700 copies. $^{62}$ Printers could not produce more copies in a short period because the manual printing presses of the era took time to operate. ${ }^{63}$ In addition, few printers employed more than one press at a time because typefaces were expensive and all type had to be set by hand. ${ }^{64}$ Of course, the total circulation of a paper does not reveal its total readership. Taverns, for example, may have kept issues of newspapers for their guests to read. Several people therefore could have looked at a single copy of a newspaper. ${ }^{65}$ How many people actually read the Federalist Papers in the New York newspapers therefore is uncertain.

Writers citing or quoting the essays as they appeared in the New York City newspapers should exercise care in identifying the source. The text and the date of publication for the essays varied slightly among the four

\footnotetext{
${ }^{61}$ See Elaine F. Crane, Publius in the Provinces: Where Was The Federalist Reprinted Outside New York City?, 21 WM. \& MARY Q. (3d ser.) 589, 590 (1964).

${ }^{6}$ See Frank L. MOTt, AMERICAN JournalisM: A History OF NEWSPAPERS IN THE UNITED STATES THROUGH 260 YEARS, 1690-1950 at 159 (rev. ed. 1950).

${ }^{63}$ See Alfred McClung LeE, The Daily Newspaper In AMERICA: The Evolution OF A SOCIAL INSTRUMENT 29 (194 7) (estimating that 1500 copies would have taken 15 to 30 hours using a manual press).

${ }^{64}$ See id.

${ }^{65}$ See MOTT, supra note 62 , at 159.
} 
newspapers. Historian Jacob E. Cooke's much cited collection reprints the first text published in any newspaper, noting variations and correcting minor typographical corrections. ${ }^{66}$

\section{(4) Publication in Other Cities}

Although Hamilton, Madison, and Jay addressed their essays to the people of New York, a few newspapers and magazines outside of New York reprinted some of what they wrote. Elaine F. Crane conducted an exhaustive search of all of the surviving issues of the 89 newspapers and three magazines published in the United States between October 27, 1787, and August $31,1788 .^{67}$ She found that sixteen newspapers and two magazines reprinted some of the essays outside of New York City. ${ }^{68}$ Collectively, these newspapers and magazines published only twenty-four of the essays, namely, numbers $1-21,23,38$, and $69 .{ }^{69}$ Publication of these essays occurred only in New York, Virginia, Pennsylvania, Rhode Island, Massachusetts, and New Hampshire. No essay appeared in print in other states.

How many people actually read the Federalist Papers outside New York City remains unknown. Hamilton and Madison mailed some copies to supporters of the Constitution in Virginia and Pennsylvania. ${ }^{70}$ In addition, some New York newspapers had interstate circulations. ${ }^{71}$ Yet, given the small number of essays published and the absence of publication in Connecticut, New Jersey, Delaware, Maryland, North Carolina, South Carolina, or Georgia, Crane concludes that the Federalist Papers "did not reach an audience of any significant size in 1787-88." "72 My computer search of the entire text of Elliot's Debates reveals no mention by any

\footnotetext{
${ }^{66}$ See THE FEDERALIST xii (Jacob E. Cooke ed., 1961).

${ }^{67}$ See Crane, supra note 61 , at 590.

${ }^{68}$ See id. at 590.

${ }^{69}$ See id.

${ }^{70}$ See Commentary No. 201, supra note 51, at 490-91.

${ }^{71}$ See Crane, supra note 61, at 591.

${ }^{72}$ Id. at 591. The American Museum, which published the first six essays, claimed a circulation of 1250 in the late 1700s, the largest of any American magazine. See FrANK L. MotT, History OF AMERICAN MAGAZINES, 1741-1850 at 14 (1930).
} 
delegate in any of the recorded debates in the various ratification conventions of the "Federalist" or of "Publius."73

\section{Content of the Federalist Papers}

Alexander Hamilton outlined the intended content of the Federalist Papers in Federalist No. 1. Writing as Publius, he promised that the essays would cover six topics:

I propose, in a series of papers, to discuss the following interesting particulars: -- The utility of the UNION to your political prosperity -

- The insufficiency of the present Confederation to preserve that Union -- The necessity of a government at least equally energetic with the one proposed, to the attainment of this object -- The conformity of the proposed constitution to the true principles of republican government -- Its analogy to your own state constitution -- and lastly, The additional security which its adoption will afford to the preservation of that species of government, to liberty, and to property. ${ }^{74}$

Hamilton further promised "to give a satisfactory answer to all the objections which shall have made their appearance." 75

The first 51 essays of the Federalist Papers generally address the first four topics listed in the outline above. Numbers 1 to 14 discuss the necessity of a strong union. Numbers 15 to 22 mostly concern problems in the Articles of Confederation. Numbers 23 to 35 address powers that will make the proposed federal government "energetic." Numbers 36-50 concern the principles of Republican government and the structure of the proposed government.

The essays numbered 52 through 84 depart somewhat from the outline. Numbers 51 to 66 describe in detail the House of Representatives and the Senate. Numbers 67 to 77 cover the Executive Branch. Numbers 78 to 83

\footnotetext{
73 The Library of Congress has a searchable version of ELLIOT'S DEBATES, supra note 23, at its website. See Library of Congress, A Century of Lawmaking for a New Nation: U.S. Congressional Documents and Debates 1774-1875 < http://memory.loc.gov/ammem/ amlaw/lwed.html> (visited Mar. 7, 2007).

${ }^{74}$ THE FEDERALisT No. 1, at 6-7 (Alexander Hamilton) (Jacob E. Cooke ed., 1961).

${ }^{75} I d$.
} 
concern the federal judiciary. Number 84 then responds to objections to the absence of a bill of rights in the Constitution.

Number 85 , the concluding essay, touches briefly on the fifth and sixth topics identified in the initial outline. It analogizes the federal Constitution to the New York constitution and talks about the additional security afforded by the Constitution. Number 85 finally urges even persons who think that the proposed Constitution has flaws to support ratification because of the difficulty of assembling a new constitutional convention and because the Constitution has procedures for amendment.

Reading the entire collection of the Federalist Papers takes a great deal of effort. Many lawyers, accordingly, look only for excerpts pertinent to their research. They may find relevant passages using citations in other works, indices included with modern reprints of the Federalist Papers, or electronic searches in computer databases. But in just looking at snippets from the Federalist Papers, researchers often fail to appreciate the magnitude of the entire project and the corresponding difficulty that Madison, Hamilton, and Jay had in making strong arguments about so many different topics. So ideally anyone relying on the Federalist Papers or contesting claims based on the Federalist Papers should try to read as much of them as time permits.

Readers who cannot tackle the entire collection may wish to know which essays have proved the most influential over time. One answer comes from a 1998 study by Ira C. Lupu. Lupu surveyed the Supreme Court's majority and other opinions and counted references to the various essays. He found that the Justices had cited (using the M'Lean numbering system) number 42 in the most cases, followed in order by numbers 78 , $81,51,32,48 \& 80$ (tied), and $44 .{ }^{76}$ While other essays also may merit special attention (like No. 10, which many academic works discuss), these eight certainly comprise a worthy subset of the collection. Reading them carefully is certainly a good start.

\footnotetext{
${ }^{76}$ See Ira C. Lupu, The Most-Cited Federalist Papers, 15 Const. COMmEnTARy 403, 404-10 (1998).
} 


\section{Judicial Consideration}

The Supreme Court first cited the Federalist Papers as evidence of the original meaning of the Constitution in 1798 in Calder v. Bull. ${ }^{77}$ In that case, the Court considered whether a Connecticut statute that had reopened the final decision of a probate court had violated the prohibition against ex post facto laws. Justice Samuel Chase's opinion said that laws generally may apply retrospectively without violating the ex post facto prohibition so long as they do not impose criminal penalties for actions that were lawful when taken. ${ }^{78}$ As authority for this position, he cited the great 18th-century legal treatise writers, William Blackstone and Richard Wooddeson. Chase added that Blackstone and Wooddeson's views were confirmed "by the author of the Federalist, who I esteem superior to both, for his extensive and accurate knowledge of the true principles of Government." 79

The Federalist Papers also played a role in the litigation of other early landmark constitutional cases. In Marbury v. Madison, ${ }^{80}$ for example, William Marbury sought a writ of mandamus from the Supreme Court directing Secretary of State James Madison to deliver his commission as a justice of the peace for the District of Columbia. Part of the dispute turned on whether the Supreme Court could exercise the power of mandamus as part of the "appellate" jurisdiction granted by Article III of the Constitution. Marbury's attorney, Charles Lee, cited Federalist No. 78 for the proposition that the "appellate" jurisdiction specified in Article III was not intended to "be taken in its technical sense" but should include mandamus jurisdiction. $^{81}$ Lee also cited Federalist Nos. 78 and 79 in arguing that a justice of the peace should be politically independent. The Federalist Papers also figured in the litigation of other constitutional landmarks, including Fletcher v. Peck, ${ }^{82}$ Martin v. Hunter's Lessee, ${ }^{83}$ M'Culloch v. Mary-

\footnotetext{
773 U.S. (3 Dall.) 386 (1798).

${ }^{78}$ See id. at 391

${ }^{79} \mathrm{Id}$. at 301.

${ }^{80} 5$ U.S. (1 Cranch) 137 (1803).

${ }^{81} 5$ U.S. (1 Cranch) at 151.

${ }^{82} 10$ U.S. (6 Cranch) 87, 122 (1810) (cited in argument of defendant in error).

${ }^{83} 14$ U.S. (11 Wheat.) 304, 313 (1816) (cited in argument of plaintiff in error).
} 
land, ${ }^{84}$ Trustees of Dartmouth College v. Woodward, ${ }^{85}$ Cohens v. State of Virginia, ${ }^{86}$ and Gibbons v. Ogden. ${ }^{87}$

Use of the Federalist Papers as legal authority has continued and substantially increased. In an exhaustive survey of the Supreme Court's reliance on the Federalist Papers, Ira Lupu says: "The data reveal (1) a striking paucity of early citations to The Federalist, (2) a 100-year plus period (1820-1929) of consistent but low frequency of citation, and (3) a series of doublings and redoublings every twenty to thirty years beginning in the 1930s." " Lupu counted over 50 citations to the Federalist Papers in the 1980 s and over 60 citations in the period form 1990 to $1998 .{ }^{89}$ Other researchers also have tallied judicial use of the Federalist Papers. ${ }^{90}$ And as noted at the start of this guide, more than 1700 cases have cited them.

\section{Theoretical Bases for Citing the Federalist as Evidence of the Original Meaning}

Judges and academic writers have cited the Federalist Papers as evidence of each of the three kinds of original intent described in part II: the original intent of the Framers, the original understanding of the ratifiers, and the original objective meaning of the Constitution. The following discussion explains the theory underlying each type of citation and provides examples. The discussion then addresses more general usage of the Federalist Papers in determining the meaning of the Constitution.

\footnotetext{
${ }^{84} 17$ U.S. (4 Wheat.) 316, 433-34 (1819).

${ }^{85} 17$ U.S. (4 Wheat.) 518, 594 n.10, 609 n.15 (1819) (cited arguments of multiple parties).

${ }^{86} 19$ U.S. (6 Wheat.) 264, 418-19 (1821).

${ }^{87} 22$ U.S. (9 Wheat.) 1, 34 n5, 38 n.9, 49 n.23 (1824) (cited in argument of respondent).

${ }^{88}$ Ira C. Lupu, Time, the Supreme Court, and the Federalist, 66 GEO. WASH. L. REV. 1324, 1329 (1998).

${ }^{89}$ See id. at 1330.

${ }^{90}$ See William H. Manz, Citations in Supreme Court Opinions and Briefs: a Comparative Study, 94 LAW LIBR. J. 267 (2002); Buckner F. Melton, Jr., The Supreme Court and The Federalist: A Citation List and Analysis, 1789-1996, 85 KY. L.J. 243 (1996/1997); James G. Wilson, The Most Sacred Text: The Supreme Court's Use of the Federalist Papers, 1985 BYU L. REV. 65.
} 
The Federalist Papers as Evidence of the Original Intent of the Framers

Many writers have cited the Federalist Papers as evidence of the original intent of the framers. The practice apparently rests on the theory (1) that Hamilton, Madison, and Jay knew the original intent of the framers, and (2) that they wanted to express it in their essays. Substantial support exists for both halves of this theory.

To the extent that the Framers of the Constitution had a clear intent, Madison and Hamilton probably knew it. They both played active roles at the Convention and they both took notes of the proceedings (although Madison took more notes). ${ }^{91}$ This participation, in the words of Chief Justice Marshall, "put it very much in their power to explain the views with which it was framed." 92 Unlike Madison and Hamilton, Jay did not attend the Constitutional Convention and thus did not have any direct knowledge of the Framers intent. History does not record whether Hamilton or Madison told Jay what had transpired there.

In addition, some of the essays making up the Federalist Papers expressly purport to describe the original intent of the framers. In Federalist No. 34, for example, Hamilton explained why the Constitutional Convention decided to give states concurrent power to impose taxes. He said:

The convention thought the concurrent jurisdiction preferable to that of subordination; and it is evident that it has at least the merit of reconciling an indefinite constitutional power of taxation in the Federal government with an adequate and independent power in the States to provide for their own necessities. ${ }^{93}$

Statements of this kind may have compromised the anonymity of the authors to some extent by revealing that the authors had first-hand knowledge of what the Convention thought, but they appear nonetheless in the Federalist Papers.

\footnotetext{
${ }^{91}$ See 1 FARRAND, supra note 9, at xv-xix, xxi (describing the notes taken by Madison and Hamilton).

${ }^{92}$ Cohens v. Virginia, 19 U.S. (6 Wheat.) 264, 418 (1821) (Marshall, C.J.).

${ }^{93}$ The Federalist No. 34, at 215 (Alexander Hamilton) (Jacob E. Cooke ed., 1961).
} 
Even when Madison and Hamilton do not expressly address the intent of the Convention, they probably were attempting to describe it. Madison and Hamilton realistically could not have put out of mind what they had seen and heard in Philadelphia. In fact, later in life, Madison explained that he had used notes from the Convention and his "familiarity with the whole subject produced by discussions there" to aid him in writing the Federalist Papers. $^{94}$

The Supreme Court has cited the Federalist Papers specifically as evidence of the original intent of the framers. In U.S. Term Limits, Inc. v. Thornton, ${ }^{95}$ for instance, an incumbent Senator challenged a state constitutional amendment designed to limit the re-election of incumbents. The Supreme Court struck down the law as an unconstitutional attempt to impose qualifications on who could serve in Congress beyond those specified in the Constitution. ${ }^{96}$ Citing the Federalist Papers, the Court said that "[t]he available affirmative evidence indicates the Framers" intent that States have no role in the setting of qualifications." 97 The Court cited Federalist No. 52, in which Madison first described the qualifications set forth in Article 1 and then said: "Under these reasonable limitations, the door of this part of the federal government is open to merit of every description, whether native or adoptive, whether young or old, and without regard to poverty or wealth, or to any particular profession of religious faith.",98

Part V, sections 4, 5, 6, and 9 discuss in depth possible grounds for impeaching claims about the original intent based on the Federalist Papers.

The Federalist Papers as Evidence of the Original Understanding of the Ratifiers

Writers do not cite the Federalist Papers only as evidence of the original intent of the Framers. On the contrary, they also commonly refer to

\footnotetext{
${ }^{94}$ Madison's Memorandum, supra note 37, at 288.

95514 U.S. 779 (U.S. 1995).

${ }^{96} \mathrm{Id}$. at 804 .

${ }^{97} \mathrm{Id}$. at 806.

${ }^{98} \mathrm{Id}$. at 806-07 (quoting THE FEDERALIST No. 52, at 325 (James Madison) (Clinton Rossiter ed., 1961).
} 
them to support claims about the original understanding of the delegates to the state ratifying conventions. The Supreme Court, in fact, has described the Federalist Papers as a source "usually regarded as indicative of the original understanding of the ratifiers of the Constitution."99

The usual theory for why the Federalist Papers provide evidence of the original understanding is simply that their publication had its intended effect. In other words, the thought is that Hamilton, Madison, and Jay's arguments in the 85 essays succeeded in influencing the minds of the participants at the state ratifying conventions who may have read or discussed them. Judge Lawrence Silberman, on this theory, has identified the Federalist Papers as "more important as an interpretative aid" than records from the Constitutional Convention "because they, unlike the records of the Convention, were available to the state ratifying conventions."100

As discussed below, this usual theory suffers from an important weakness: there is substantial reason to doubt that many of the ratifiers actually read the Federalist Papers. ${ }^{101}$ But I see another theoretical basis for citing the Federalist Papers as evidence of the original understanding of the ratifiers. Even if the Federalist Papers did not influence the ratification debates, the ratification debates may have influenced the Federalist Papers. Madison, Hamilton, and Jay knew what proponents and opponents of the Constitution were arguing in 1787 and 1788. ${ }^{102}$ This knowledge undoubtedly had an impact on what they wrote. The Federalist Papers accordingly may serve as a record of what proponents of ratification generally were thinking.

Chief Justice Salmon P. Chase cited the Federalist Papers as evidence of the original understanding of the Constitution in his famous dissent in the Legal Tender Cases. ${ }^{103}$ In that decision, the majority of the Court held that Congress could authorize the issuance of paper currency. ${ }^{104}$ Chief

\footnotetext{
${ }^{99}$ Printz v. United States, 521 U.S. 898, 910 (1997).

${ }^{100}$ In re Sealed Case, 838 F.2d 476, 492 (D.C. Cir.), reversed sub nom. Morrison v. Olson, 487 U.S. 654 (1988).

${ }^{101}$ See infra part V.1.

102 See Commentary No. 201, supra note 51, at 488 (“'Publius' was fully aware of and concerned with the influential Antifederalist literature appearing almost daily in newspapers, broadsides, and pamphlets.").

10379 U.S. (12 Wall.) 457, 585 (1870) (Chase, C.J., dissenting).

${ }^{104} \mathrm{Id}$. at 553-554 (overruling Hepburn v. Griswold, 75 U.S. (8 Wall.) 603 (1869).
} 
Justice Chase, asserted that the congressional power to "coin Money" under the Constitution did not extend so far. ${ }^{105}$ He supported this position by citing the Federalist Papers, which he considered evidence of the original understanding of the ratifiers:

The papers of the Federalist, widely circulated in favor of the ratification of the Constitution, discuss briefly the power to coin money, as a power to fabricate metallic money, without a hint that any power to fabricate money of any other description was given to Congress; and the views which it promulgated may be fairly regarded as the views of those who voted for adoption. ${ }^{106}$

Although Chase's view did not prevail, the Court has continued to cite the Federalist Papers to show the original understanding of the ratifiers. ${ }^{107}$

Part V, sections 1, 2, 3, 8 and 9 address possible grounds for impeaching claims about the original understanding of the Constitution based on the Federalist Papers.

\section{The Federalist Papers as Evidence of the Original Objective Meaning}

The original objective meaning of the Constitution is the meaning that a reasonable person at the time of the founding would have understood from the text and structure of the Constitution. One way to determine how readers would have understood words and phrases in the Constitution at the time of the framing is to examine how other works from the founding era used the same words and phrases. How does this concern the Federalist Papers? The Federalist Papers are texts from 1787 and 1788. They use many of the same terms found in the Constitution. So examining the Federalist Papers may yield clues about the objective meaning of the 18thcentury language used in the Constitution.

An example appears in Justice Thomas's concurrence in United States v. Lopez. ${ }^{108}$ In that case, the Court held that Congress's power to regulate commerce among the states did not permit it to criminalize the possession

\footnotetext{
${ }^{105}$ Id. at 584-585 (Chase, C.J., dissenting).

${ }^{106} \mathrm{Id}$. at 585 (footnote omitted).

${ }^{107}$ See, e.g., Printz v. United States, 521 U.S. at 910.

${ }^{108}$ United States v. Lopez, 514 U.S. 549, 585 (1995) (Thomas, J., concurring).
} 
of guns in schools. ${ }^{109}$ Justice Thomas concurred, asserting that the term "commerce" could not embrace the mere possession of a gun in a school. ${ }^{110}$ To support this position, Justice Thomas cited several period dictionaries. ${ }^{111}$ He then added:

In fact, when Federalists and Anti-Federalists discussed the Commerce Clause during the ratification period, they often used trade (in its selling/bartering sense) and commerce interchangeably. See The Federalist No. 4, p. 22 (J. Jay) (asserting that countries will cultivate our friendship when our "trade" is prudently regulated by Federal Government); id., No. 7, at 39-40 (A. Hamilton) (discussing "competitions of commerce" between States resulting from state "regulations of trade"); id., No. 40, at 262 (J. Madison) (asserting that it was an "acknowledged object of the Convention . . . that the regulation of trade should be submitted to the general government"); Lee, Letters of a Federal Farmer No. 5, in Pamphlets on the Constitution of the United States 319 (P. Ford, ed., 1888); Smith, An Address to the People of the State of New York, in id., at 107. ${ }^{12}$

In this passage, Justice Thomas is not making a claim about what the framers specifically intended or about what the ratifiers actually understood the Commerce Clause to mean. Instead, he is talking only about what the term "commerce" ordinarily meant. Other cases also have followed this approach. ${ }^{113}$ In addition, Justice Antonin Scalia has endorsed this use of the Federalist Papers in his private writings. ${ }^{114}$

\footnotetext{
${ }^{109}$ Id. at 551 .

${ }^{110} \mathrm{Id}$. at 585 .

111 See id. (citing 1 S. Johnson, A Dictionary OF THE ENGLish LANGUAGE 361 (4th ed. 1773) (defining commerce as "Intercour[s]e; exchange of one thing for another; interchange of any thing; trade; traffick"); N. BAILEY, AN UNIVERSAL ETYMOLOGICAL ENGLISH DICTIONARY (26th ed. 1789) ("trade or traffic"); T. SHERIDAN, A COMPLETE DictionARY OF THE ENGLiSH LANGUAGE (6th ed. 1796) ("Exchange of one thing for another; trade, traffick").

${ }^{112} I d$. at 586.

113 See Federal Maritime Commission v. South Carolina State Ports Authority, 535 U.S. 743 (2002) (citing the Federalist Papers as a source "[r]eflecting the widespread understanding at the time the Constitution was drafted").

${ }^{114}$ See Scalia, supra note 12, at 38 (1997).
} 
Part $\mathrm{V}$, section 7 addresses a possible ground for impeaching claims about the original objective meaning of the Constitution based on the Federalist Papers.

\section{Authority of the Federalist Papers Independent of Original Meaning}

The foregoing discussion has shown how courts often have cited the Federalist Papers as evidence of the original meaning of the Constitution. Sometimes though judges have relied on the Federalist Papers as an authoritative commentary on the Constitution, without suggesting that it shows anything about what the framers intended, ratifiers understood, or reasonable persons of the era would have thought. In other words, they have viewed the Federalist Papers much like a persuasive academic treatise on Constitutional Law. The Supreme Court's decision in Calder v. Bull, ${ }^{115}$ discussed at the end of part III, is a possible example. The Court appears to have cited the authors of the Federalist for their legal expertise (much like it cited Blackstone's treatise) rather than for their insights into the original meaning of the Constitution. ${ }^{116}$

William N. Eskridge Jr. and David McGowan believe that most judges traditionally have used the Federalist Papers in this manner. ${ }^{117}$ Eskridge has said:

[J]udicial interpreters of the Constitution often rely heavily upon the Federalist Papers, surely not because anyone can demonstrate that Madison, Hamilton, and Jay represented the views of the Philadelphia convention or of the state ratifying conventions, but instead because they are authoritative statements, because they have become focal points, and (perhaps most of all) because they are intelligent analysis based upon sophisticated political theory. ${ }^{118}$

\footnotetext{
1153 U.S. (3 Dall.) 386 (1798).

116 See id. at 301 (praising the authors for their "extensive and accurate knowledge" of the law).

${ }^{117}$ See David McGowan, Ethos in Law and History: Alexander Hamilton, the Federalist, and the Supreme Court, 85 MINN. L. REV. 755, 755-56 (2001); William N. Eskridge, Jr., Cycling Legislative Intent, 12 INT’L REV. L. \& ECON. 260, 261 (1992).

${ }^{118}$ Eskridge, supra note 117, at 261.
} 
As a descriptive matter, McGowan and Eskridge's theory that most judges have cited the Federalist Papers without attempting to make claims about the original meaning is questionable. Many judicial decisions, like the ones quoted above, expressly say that the Federalist Papers demonstrate the intent of the framers, the understanding of the ratifiers, or the original objective meaning of the Constitution. To the extent that judges are using the Federalist Papers for reasons other than as evidence in support of claims about the original meaning, further analysis of that practice lies outside the scope of this guide.

\section{POTENTIAL GROUNDS FOR IMPEACHING CLAIMS ABOUT THE ORIGINAL MEANING BASED ON THE FEDERALIST PAPERS}

Writers who cite excerpts from the Federalist Papers to support claims about the original meaning of the Constitution must take into account a variety of potential challenges to their arguments. These challenges fall into two groups. Some are general grounds for doubting almost any claims about the original meaning. For instance, some writers have argued that all efforts to discern the original intent or the original understanding of the Constitution must fail because the framers and ratifiers consisted of large groups of people who probably did not have a single intent or understanding. ${ }^{119}$ In addition to general arguments of this sort, some more specific contentions address special problems concerning the Federalist Papers. Both types of objections are important. But this guide focuses only on those specific to the Federalist Papers.

The following discussion identifies and explains nine special reasons for doubting whether the Federalist Papers can establish the original meaning of the Constitution. Each of these reasons has substantial merit. But each is also subject to counterargument. Anyone making or evaluating an argument based on the Federalist Papers should take both sides into account.

119 See, e.g., Ronald Dworkin, The Forum of Principle, 56 N.Y.U. L. REV. 469, 477 (1981) ("[T]here is no such thing as the intention of the Framers waiting to be discovered, even in principle. There is only some such thing waiting to be invented."). 
1. Delegates to the state ratifying conventions could not or did not read many of the Federalist Papers.

Judges and authors, as explained in part IV, sometimes rely on the Federalist Papers to make claims about the original understanding of the ratifiers of Constitution. These claims sometimes rest on the assumption that the Federalist Papers influenced the minds of the delegates at the state ratification conventions. An argument against this assumption is that most delegates probably could not or did not read the Federalist Papers. The Federalist Papers thus seem unlikely to have affected their understanding of the Constitution. In fact, three separate but related grounds exist for doubting that very many ratifiers read the Federalist Papers:

First, ratifiers in several states could not have read much of the Federalist Papers before voting on the Constitution simply because many of the essays were published too late. Table \#2 shows the dates of ratification for each state and the number of Federalist Papers (using the M'Lean numbering system) published before the date of ratification:

TABLE \# 2

Number of Essays Published Before Date of Ratification in Each State

\begin{tabular}{|l|l|l|}
\hline State & Ratification & Essays \\
\hline Delaware & December 7, 1787 & 17 \\
\hline Pennsylvania & December 12, 1787 & 20 \\
\hline New Jersey & December 18, 1787 & 22 \\
\hline Georgia & January 2, 1788 & 31 \\
\hline Connecticut & January 9, 1788 & 36 \\
\hline Massachusetts & February 6, 1788 & 49 \\
\hline Maryland & April 28, 1788 & 77 \\
\hline South Carolina & May 23, 1788 & 77 \\
\hline New Hampshire & June 21, 1788 & 85 \\
\hline
\end{tabular}




\begin{tabular}{|l|l|l|}
\hline Virginia & June 25, 1788 & 85 \\
\hline New York & July 26, 1788 & 85 \\
\hline North Carolina & November 21, 1789 & 85 \\
\hline Rhode Island & May 29, 1790 & 85 \\
\hline
\end{tabular}

This table shows that the first eight states to ratify the Constitution acted before Hamilton, Madison, and Jay completed writing their 85 essays. As the table indicates, Federalist Nos. 18 through 85 could not have influenced the opinions of the delegates to the Delaware ratifying convention because these essays first appeared after Delaware's date of ratification. Similarly, Federalist Nos. 21 through 85 could not have influenced the ratification process in Pennsylvania, and so forth.

To make this objection concrete, consider the familiar and very important issue of whether the ratifiers of the Constitution believed that federal courts under the Constitution would have the power to review the constitutionality of federal statutes. Countless books and law review articles have observed that Madison specifically endorsed judicial review of legislation in the following passage from Federalist No. 78:

A constitution is, in fact, and must be regarded by the judges, as a fundamental law. It therefore belongs to them to ascertain its meaning, as well as the meaning of any particular act proceeding from the legislative body. If there should happen to be an irreconcilable variance between the two, that which has the superior obligation and validity ought, of course, to be preferred; or, in other words, the Constitution ought to be preferred to the statute, the intention of the people to the intention of their agents. ${ }^{120}$

Although this passage directly addresses the issue of judicial review, it could not have influenced the minds of the delegates in the first eight states that ratified the Constitution because it was published after they already had voted.

${ }^{120}$ The Federalist No. 78, at 525 (Alexander Hamilton) (Jacob E. Cooke ed., 1961). 
Second, even the essays that were published prior to ratification in the various states may not have affected the views of the delegates to ratification conventions in those states simply because they never reached most of the delegates. The Federalist Papers had a very small circulation. As described in part III, the New York newspapers probably printed at most about six hundred copies of each essay. The publishers of the M'Lean Edition sold, prior to October 1788, only a fraction of the 500 copies printed. In addition, the best research shows that only 24 of the essays were published in states other than New York. Finally, none of the essays were published in Connecticut, New Jersey, Delaware, Maryland, North Carolina, South Carolina, or Georgia. The particular statements in the Federalist Papers therefore could not have established the general understanding of the ratifiers in most states.

Third, even assuming that the ratifiers had access to some of the essays, a question remains as to whether they actually read them. The Federalist Papers have many brilliant passages, but they also contain tedious discussions that surely prevented some people from digesting them thoroughly. Larry D. Kramer has collected a list of quotations from the period raising doubts of this kind about the actual reading of the Federalist Papers. ${ }^{121}$ In Maryland, for example, Alexander Contee Hanson said of the collection of essays: "It is an ingenious, elaborate, and in some places, sophistical defence of the constitution. . . . Altho written in a correct, smooth stile it is from its prolixity, tiresome. I honestly confess, that I could not read it thro' ...."122 The French chargé d'affaires at the time wrote that the collection "is not at all useful to educated men and it is too scholarly and too long for the ignorant." 123 Contemporaneously Archibald Maclaine of North Carolina said that the essays were not "well calculated for the common people." 124

Some confirmation of the arguments that few ratifiers actually read the Federalist Papers comes from the extensive records of the state ratification debates. As mentioned above, my computer search of the entire text of

121 See Larry D. Kramer, Madison's Audience, 112 HARV. L. REV. 611, 665 n.237 (1999).

${ }^{122} \mathrm{Id}$.

${ }^{123} \mathrm{Id}$.

${ }^{124} \mathrm{Id}$. 
Elliot's Debates reveals no mention by any delegate in any of the recorded debates in the various ratification conventions of the "Federalist" or of "Publius." 125 For all of these reasons, claims that the Federalist Papers generally influenced the original understanding of the Constitution seem rather weak.

But are there any counterarguments to these valid points? I see three of them. The first counterargument is that the success of the Constitution depended crucially on the opinions of Virginia and New York. Although nine states had ratified the Constitution before Virginia and New York, the new republic most likely could not have thrived without the participation of these two large, populous, and geographically central states. And although the ratifiers at other states may not have known what the Federalist Papers said, a significant number of the ratifiers in New York and Virginia may have read them. As explained in part III, we know that many delegates at these conventions had copies of the M'Lean Edition. In addition, we know that Hamilton repeated many of the arguments from the Federalist Papers during his speeches at the New York ratification debates. ${ }^{126}$

The second counterargument is that even if the Federalist Papers did not influence many of the ratifiers, they clearly expressed the views of at least some of the most important ratifiers: Hamilton, Jay, and Madison. Hamilton and Jay played prominent roles at the New York ratifying convention, and Madison did the same at the Virginia ratifying convention. Because of the Federalist Papers, we know how these three ratifiers understood the Constitution. ${ }^{127}$ It is not a great stretch to imagine that other ratifiers had similar thoughts.

The third counterargument is that the Federalist Papers may reflect the original understanding even if no one read them. The essays, as explained in part IV, may serve as a record of the kinds of arguments that persuaded

\footnotetext{
${ }^{125}$ See supra note 73.

${ }^{126}$ See Raoul Berger, Original Intent and Boris Bittker, 66 IND. L.J. 723, 743 \& n.152 (1991).

${ }^{127}$ Because the authors of the Federalist had to rebut legitimate arguments of the antiFederalist, William N. Eskridge Jr. has questioned whether "The Federalist even honestly reflects the views of Madison and Hamilton themselves." William N. Eskridge Jr., Should the Supreme Court Read The Federalist But not Statutory Legislative History?, 66 GEO. WASH. L. REV. 1301, 1309 (1998).
} 
the delegates at the state ratification conventions to approve the Constitution. Hamilton, Madison, and Jay knew the issues being debated by the proponents and opponents of the Constitution. They had good reason to incorporate the proponents' best arguments into the Federalist Papers.

In sum, no one can deny that only a small fraction of the ratifiers read the Federalist Papers before voting on whether to ratify the Constitution. But some did have the opportunity, and these included some of the most important ratifiers in some of the most important states. And the Federalist Papers may have reflected the original understanding even if they did little to shape it. So the Federalist Papers are neither worthless as evidence of the original understanding nor are they flawless proof. Their value lies somewhere in between.

\section{The Federalist Papers may not have been persuasive to the ratifiers.}

Even if the delegates to the state ratifying conventions read the Federalist Papers or indirectly knew of their content, they may not have found them persuasive. Accordingly, although the Federalist Papers may have expressed views on the meaning of the Constitution, these views may not have accorded with the original understanding. Several reasons exist for questioning the extent to which the ratifiers may have accepted what the Federalist Papers said.

First, the ratifiers may have distrusted or discounted the Federalist Papers to some extent because they recognized them as a form of partisan advocacy rather than politically neutral analysis. Regardless of how brilliant, thoughtful, and insightful Hamilton, Madison, and Jay were in writing the Federalist Papers, they naturally wanted to present the Constitution in the best light possible and to gloss over contrary arguments. Even very early on, writers recognized this problem. When the Virginia Supreme Court decided Hunter v. Martin's Lessee (which later went to the United States Supreme Court), Justice Spencer Roane made the following assessment of the Federalist Papers:

With respect to the work styled "the Federalist," while it's general ability is not denied, it is liable to the objection, of having been a mere newspaper publication, written in the heat and hurry of the battle, (if I may so express myself,) before the constitution was 
adopted, and with a view to ensure its ratification. It's principal reputed author [i.e., Hamilton] was, an active partizan of the constitution, and a supposed favourer of a consolidated government. ${ }^{128}$

Modern writers repeat this skepticism about the reliability and likely influence of the Federalist Papers' political arguments. ${ }^{129}$

Second, ratifiers may have discounted the arguments made in the Federalist Papers because they were written anonymously. Some scholars have suggested that readers would have viewed any pseudonymous writing with suspicion. John F. Manning, for example, asks whether courts today would rely on anonymous newspaper editorials written in favor of legislation in interpreting the legislation. ${ }^{130}$ A counterargument is that almost all of the proponents and opponents of the Constitution at the time were writing anonymously, ${ }^{131}$ suggesting that readers did not expect signed essays.

Yet, even if readers of the era did not view all anonymous writing with suspicion, they still would not have known what weight to give the opinions expressed in the Federalist Papers. We now pay careful attention to anything that Hamilton, Madison, and Jay ever wrote because we are fully aware of what these great men accomplished in their lifetimes. The ratifiers, however, had little idea that the men calling themselves Publius had distinguished careers, and that two of them had played important roles in the Constitutional Convention. They certainly could not guess that the authors later would become Secretary of Treasury, Secretary of State, President, and Chief Justice of the United States. Our perceptions of what weight the ratifiers should have given the Federalist Papers, in other

\footnotetext{
${ }^{128}$ Hunter v. Martin, 18 Va. 1, 27 (Va. 1813).

129 See Joseph M. Lynch, The Federalists and the Federalist: a Forgotten History, 31 SEtON HALl L. REV. 18, 26-27 (2000) (citing Justice Roane's opinion); Norman R. Williams, The Failings of Originalism: The Federal Courts and the Power of Precedent, 37 U.C. DAVIS L. REV. 761, 809-10 (2004) (arguing that while the authors of the Federalist Papers were not political "spin-doctors," their readers may not have given much weight to what they said).

${ }^{130}$ See John F. Manning, Textualism and the Role of the Federalist in Constitutional Adjudication, 66 GEO. WASH. L. REV. 1337, 1354 (1998) (saying "[a]s a piece of advocacy--and an anonymous one at that--The Federalist lacks similar usefulness as a window into the reasonable ratifier's likely understanding.").

${ }^{131}$ See supra part III.
} 
words, may differ from what the ratifiers thought when confronted with the anonymous writings.

Third, readers of the Federalist Papers may have viewed the essays as an unreliable source because they contain numerous errors. Seth Barrett Tillman, in a humorous article with a serious point, notes that Hamilton, Madison, and Jay, among other mistakes, misstated the quorum requirement, did not count the members of Congress properly, incorrectly described the powers of the Vice President, and showed a fundamental misunderstanding about the process of electing the President. ${ }^{132}$ Although we now forgive these errors because we know the haste with which Madison, Hamilton, and Jay wrote the Federalist Papers, errors of these kinds presumably did not help to persuade ratifiers.

Fourth, the authors of the Federalist Papers often took positions on issues without providing explanations or arguments. For example, politicians recently have debated the role of the Senate in judicial nominations. In Federalist No. 66, Hamilton addresses the nomination process, saying:

It will be the office of the President to nominate, and, with the advice and consent of the Senate, to appoint. There will, of course, be no exertion of choice on the part of the Senate. They may defeat the choice of the Executive, and oblige him to make another; but they cannot themselves choose, they can only ratify or reject the choice of the President. ${ }^{133}$

Politicians opposed to inaction by the Senate have focused on the last clause, saying that the Senate "can only ratify or reject the choice of the President" and therefore cannot insert itself into the nomination process. ${ }^{134}$ Hamilton, however, does not say how he reached that conclusion. Thus, even if the ratifiers had read the Federalist Papers and had thought about the issue, why would they have accepted this position?

\footnotetext{
132 See Seth Barrett Tillman, The Federalist Papers as Reliable Historical Source Material for Constitutional Interpretation, 105 W. VA. L. REV. 601, 603-617 (2003).

${ }^{133}$ The Federalist No. 66, at 449 (Alexander Hamilton) (Jacob E. Cooke ed., 1961) (emphasis in original).

${ }^{134}$ See, e.g., Orrin G. Hatch, Presidential Privilege, NAT'L REVIEW OnLINE, Jul. 14, 2005 (available on NEXIS) (quoting this passage).
} 
Fifth, the delegates to the various state ratifying conventions also may have discounted the Federalist Papers because when the authors did express their reasoning, their arguments often had flaws. Justice Spencer Roane's early opinion in Martin v. Hunter's Lessee also mentions an example of this problem. The issue in the case was whether the Supreme Court could review a state court determination of federal law. Justice Roane did not think the Federalist Papers provided a satisfactory answer. Criticizing the reasoning of the relevant passage from the Federalist, he wrote:

It is also liable to the objection, that while it contains an ample stock of principles, to bear out every opinion I have formed on this subject, its conclusions, in relation to the particular question now before us, go to prove too much: they go to authorise an appeal from the highest State Courts, to the inferior Federal Tribunals! ${ }^{135}$

Another well-known example concerns arguments in the Federalist Papers about the need for a Bill of Rights. Responding to opponents who wanted protection of freedom of speech and freedom of the Press, Hamilton argued in Federalist No. 84 that these guarantees were not necessary. Reasoning that Congress had no express power to infringe these powers, he asked rhetorically "why declare that things shall not be done which there is no power to do?" 136 This argument has an obvious flaw; Congress's power to regulate interstate commerce clearly would allow it to regulate the interstate sale of newspapers, including their content, unless the Constitution provided a separate protection of speech or press.

Sixth, the delegates to the state ratifying conventions did not have to rely on what the Federalist Papers said because they had many competing sources of information about the Constitution. Although Hamilton, Madison, and Jay wrote more than others, a variety of other authors also were publishing essays in support of or in opposition to the proposed Constitution. ${ }^{137}$ Delegates, therefore, may have balanced what the Federalist Papers said with what other they read elsewhere.

\footnotetext{
${ }^{135}$ Hunter v. Martin, 18 Va. at 26.

${ }^{136}$ ThE FederALIST No. 84, at 579 (Alexander Hamilton) (Jacob E. Cooke ed., 1961).

137 See ThE COMPLETE ANTI-FEDERALIST, supra note 22 (multi-volume collection of writing opposing ratification of the Constitution).
} 
These six arguments, like the arguments about whether the ratifiers read the Federalist Papers, all cast doubt on claims that the Federalist Papers reflect the original understanding of the Constitution. Yet, these arguments also must confront a stubborn fact, namely, that when all was said and done, the states ultimately ratified the Constitution. Some considerations and arguments must have persuaded the delegates at the state ratification conventions to approve the Constitution. The arguments in the Federalist Papers seem like worthy candidates because of their breadth and detail, because of their sophisticated tone, and because of their often new and important political insights. Raoul Berger, a great champion of originalism, has contended that "the fact that ratification carried testifies that the persuasion was effective."138

This response is significant, but it should not be overstated. We cannot know merely from looking at the Federalist Papers which arguments the many ratifiers found persuasive and which arguments they did not. In addition, ratifiers may have decided to approve the Constitution for reasons unrelated to any arguments in the Federalist Papers. ${ }^{139}$ For example, some historians think that New York ratified the Constitution because it did not want to be left out after nine other states already had ratified it. ${ }^{140}$ Others say that New York ratified the Constitution because the City of New York threatened that otherwise it would secede from the state if the convention did not ratify the Constitution. ${ }^{141}$ The Federalist Papers thus may have little to do with New York's ratification decision.

So again, arguments exist on both sides. Readers of the Federalist Papers would have had good reasons not to find the content of the essays persuasive. But on the other hand, they did vote for ratification, and the Federalist Papers may have influenced their decision. Proponents of claims about the original understanding based on the Federalist Papers,

\footnotetext{
${ }^{138}$ Berger, supra note 126 , at 743 (1991).

139 See McGowan, supra note 117, at 829 (arguing that "[t]here is no solid evidence that The Federalist swayed any votes").

${ }^{140}$ See John P. Kaminski, New York: The Reluctant Pillar, in The ReluCTANT PILlAR: NeW York AND THE AdOPTION OF THE FEDERAL CONSTITUTION 115 (Stephen L. Schechter ed., 1985).

${ }^{141}$ See Forrest McDonald, ALEXANDER HAMilton 115 (1979) (noting that Jay and Hamilton announced that New York City would "secede from the state and join the Union" if New York did not ratify).
} 
and skeptics regarding these claims, must take these two opposing considerations into account.

\section{The Federalist Papers are often self-contradictory.}

An old joke tells of a religious man so pious that he vowed to follow all of the scriptures, even the parts that contradict each other. Anyone attempting to adhere to all of the views expressed in the Federalist Papers would face a similar challenge. Put quite simply, numerous statements and arguments in the 85 essays conflict.

The Supreme Court recently faced this problem in United States v. Printz. ${ }^{142}$ The Court recognized that Federalist No. 44 and No. 27 appear to disagree about whether the federal government may require state officials to implement federal laws. ${ }^{143}$ In Federalist No. 44, Madison suggested that it could not, saying that laws enacted under the Constitution "will, probably, forever be conducted by the officers and according to the laws of the States." 144 In Federalist No. 27, however, Hamilton intimated the opposite, writing that the "legislatures, courts, and magistrates, of the respective members [i.e., states] will be incorporated into the operations of the national government as far as its just and constitutional authority extends; and will be rendered auxiliary to the enforcement of its laws." "145

Quoting Daan Braveman, William Banks, and Rodney Smolla, the Court simply acknowledged that "The Federalist reads with a split personality' on matters of federalism." 146 The Court then decided to follow Madison's views. It rejected what Hamilton said in Federalist No. 27, finding Hamilton's positions less credible because they represented the "most expansive view of federal authority ever expressed, . . . from the pen of the most expansive expositor of federal power."147

142521 U.S. 898, 915 (U.S. 1997).

${ }^{143}$ The Federalist No. 27, at 177 (A. Hamilton) (Jacob E. Cooke ed., 1961) (emphasis in original).

144 The Federalist No. 44, at 307 (James Madison) (Jacob E. Cooke ed. 1961).

${ }^{145}$ The Federalist No. 27, at 175 (Alexander Hamilton) (Jacob E. Cooke ed., 1961).

146521 U.S. at 915 n.9 (quoting DAAN BRAVEMAN ET AL., CONSTITUTIONAL LAW: STRUCTURE AND RightS IN OUR FEDERAL SYSTEM 198-199 (3d ed. 1996)).

${ }^{147} I d$. 
Legal scholars have identified numerous other conflicts or apparent conflicts in the Federalist Papers. For example, Federalist No. 62 says that senators serve to protect state interests while Federalist No. 63 says that they best protect federalist interests. ${ }^{148}$ Federalist No. 29 envisions a select militia, while Federalist No. 46 endorses a more general militia. ${ }^{149}$ Federalist No. 80 says there must be some effective way of insuring that states comply with federal law, while Federalist No. 81 says that state sovereignty prevents a federal court from entertaining an individual suit against a state. $^{150}$

The presence of some discrepancies in the 85 essays should not come as a surprise. The three authors of the Federalist Papers worked in a hurry and made an ample number of mistakes. In addition, Madison and Hamilton, who wrote most of the Federalist Papers, did not see eye to eye on various matters at the Constitutional Convention, and they did not coordinate or review each other's work before publication. They understandably may have carried some of their disagreements into their essays, which they wrote separately without consulting each other.

Anyone attempting to discern the original meaning of the Constitution might react to the presence of contradictions in the Federalist Papers in three different ways. One reaction would be to dismiss the entire collection of essays as unreliable. This reaction finds general support in the theory, mentioned above, that the framers and ratifiers may not have had a single intent or understanding of the Constitution. "151 "Ask yourself," a critic may say, "if Hamilton, Madison, and Jay could not agree when working together on a common project, how could general agreement exist among all of the other framers and ratifiers?")

A second, less extreme, reaction would be to dismiss as unreliable any passages in the Federalist Papers that actually conflict but generally to ac-

\footnotetext{
148 See Timothy Zick, The Consent of the Governed: Recall of United States Senators, 103 DiCKENSON L.R. 567 n.180 (1999).

${ }^{149}$ See David Thomas Konig, The Second Amendment: a Missing Transatlantic Context for the Historical Meaning of "The Right of the People to Keep and Bear Arms, " 22 LAW \& HIST. REV. 119, 152 (2004).

${ }^{150}$ See Ana Maria Merico-Stephens, Of Maine's Sovereignty, Alden's Federalism, and the Myth of Absolute Principles: the Newest Oldest Question of Constitutional Law, 33 U.C. Davis L. Rev. 325, 364 (2000).

${ }^{151}$ See H. Jefferson Powell, Rules for Originalists, 73 VA. L. REV. 659, 684-87 (1987).
} 
cept other passages. This approach concedes that the Federalist Papers contain imperfections and cannot unambiguously answer all questions, while still recognizing its general coherency. And, in reality, the authors' disagreements are minor in comparison to their overall unity when it comes to basic assumptions about the Constitution.

The Printz case represents a third reaction: when facing a conflict between two passages, follow the passage that appears better supported by extrinsic considerations. In Printz, as explained above, the Court accepted what Madison said because it thought that Madison had more credibility on federalism issues given Hamilton's extreme nationalist views. This third approach sounds reasonable, but it too has difficulties. If the ratifiers of the Constitution did not have access to the extrinsic evidence, the evidence could not have aided their understanding of the Constitution. The delegates to the state ratifying conventions did not know who had proposed what at the Constitutional Convention because of the secret nature of the proceedings. The ratifiers also did not know that Hamilton, Madison, and Jay were the authors of the Federalist Papers or how they divided their work. They thus did not have access to the information the Court relied on in Printz. In my view, when attempting to discern the ratifiers' understanding, if passages in the Federalist Papers conflict, and choosing one over the other becomes necessary, the choice should turn on information available to the ratifiers. For example, one of the essays may contain better reasoning or more details than the other.

\section{Hamilton and Jay are not ideal expositors of the original intent of the Framers.}

The Federalist Papers also may have a specific shortcoming when cited as evidence of the original intent of the Framers (as opposed to the original understanding or original objective meaning). Hamilton and Jay, who together wrote over half the essays, were not ideal expositors of the original intent of the Framers. Jay did not attend the Constitutional Convention. As Michael Dorf has observed, he therefore did not know what tran- 
spired there. ${ }^{152}$ He would have information about the proceedings only if Hamilton, Madison, or someone else broke the rule of secrecy and told him, and the historical record does not establish whether anyone did or not. Even if someone did inform Jay what happened, all of Jay's knowledge of the original intent would be hearsay.

Although Hamilton attended the Constitutional Convention, several factors may weaken his reliability in reporting the original intent. ${ }^{153} \mathrm{Ham}$ ilton missed some of the Convention, ${ }^{154}$ took few notes, ${ }^{155}$ and did not vote after his delegation departed. ${ }^{156}$ In addition, as noted above, Hamilton expressed extreme nationalist views that put him at odds with the other members of the Convention. These problems would not absolutely have prevented Hamilton from describing the original intent in an accurate manner, but they certainly would make it more difficult for him.

But on the other hand, this ground for impeaching claims about the original intent cannot apply to Madison. Madison attended the entire Convention and took copious notes. ${ }^{157}$ He would have known the original intent of the framers as well as anyone.

${ }^{152}$ See Michael C. Dorf, Integrating Normative and Descriptive Constitutional Theory: The Case of Original Meaning, 15 GEO. L.J. 1765, 1804 n.193 (1997) (emphasizing that Jay did not attend the Constitutional Convention)

${ }^{153}$ See James W. Ducayet, Note, Publius and Federalism: on the Use and Abuse of the Federalist in Constitutional Interpretation, 68 N.Y.U. L. REV. 821, 845 (1993) (discussing whether Hamilton can provide an accurate view of the original intent).

${ }^{154}$ See 3 FARRAND, supra note 9, at 589 (saying that Hamilton "[a]ttended on May 18; left Convention June 29; was in New York after July 2; appears to have been in Philadelphia on July 13; attended Convention August 13; was in New York August 20-September 2").

${ }^{155}$ See 1 FARRAND, supra note 9, at xxi (saying that Hamilton's notes "are little more than brief memoranda" and of not much importance "in determining what others thought or said").

${ }^{156}$ The Convention adopted a rule permitting a state to vote only when "fully represented." Id. at 8 (Journal, May 28, 1787). This rule prevented Hamilton from voting on behalf of New York, but did not prevent him from speaking. At the close of the Convention, Hamilton signed the Constitution as a witness that the Convention was acting with the "unanimous consent of the states present." U.S. Const. art. VII. This affirmation was true; although New York did not consent, it was not "present" after Lansing and Yates departed.

${ }^{157}$ See 1 FARRAND, supra note 9, at xv-xix (describing Madison's thorough notes and comparing them to those of other deputies). 
5. The secrecy of the Constitutional Convention makes the Federalist Papers an unreliable source of the original intent of the Framers.

A fifth argument for impeaching claims about the original meaning concerns the trustworthiness of what Hamilton and Madison said about the original intent. Some writers, as previously shown, cite the Federalist Papers for evidence of the original intent of the Framers. They believe, perhaps correctly, that the authors of the Federalist Papers knew the original intent and generally tried to express it. But the accuracy of the Federalist Papers is open to doubt for a simple reason: Given the secrecy of the Convention, other deputies may have felt inhibited to dispute anything that the Federalist Papers said about the original intent. The authors of the Federalist Papers therefore could have distorted purposefully (or even accidentally) the original intent without much fear of contradiction. ${ }^{158}$

Consider, for example, the power of taxation. Article I, section 8, clause 1 of the Constitution gives Congress the power to impose taxes. ${ }^{159}$ But did the Framers intend this taxation power to be an exclusively federal power or did the Framers intend the states also to retain a power of taxation? Hamilton answers this question in Federalist No. 34. He says that "the Convention thought" that the federal government and the states should have "concurrent jurisdiction" over taxation. ${ }^{160}$ But in making this statement, Hamilton knew that his readers would simply have to take his word for it. They had no access to the records of the Constitutional Convention. And no participant at the Constitutional Convention could contradict him in a convincing manner (i.e., by saying, "I was there and that is not what we thought") without breaching the confidentiality of the Convention. Hamilton therefore could have been misrepresenting the original intent.

The counterargument, though, is that Hamilton and Madison probably had little reason to want to misrepresent what the Convention intended. ${ }^{161}$

\footnotetext{
${ }^{158}$ See Eskridge, supra note 104, at 1309.

${ }^{159}$ U.S. Const. art. I, $\S 8$, cl. 1 ("The Congress shall have power to lay and collect taxes, duties, imposts and excises ....").

${ }^{160}$ The FedERALIST No. 34, at 215 (Alexander Hamilton) (Jacob E. Cooke ed., 1961).

${ }^{161}$ A reply might be the authors of the Federalist Papers were making insincere arguments in an effort to secure ratification. See Eskridge, supra note 104, at 1309.
} 
And although they made some mistakes, there is little ground for disbelieving everything that they wrote. Critics who want to impeach claims about the original intent would do better to examine the records of the Constitutional Convention (which are now available) and find contradictory evidence. The next section considers this possibility.

6. Statements in the Federalist Papers often conflict with other sources.

Even if the Federalist Papers provide some evidence of the original meaning of the Constitution on particular issues, they often do not supply the only evidence available. On the contrary, in addition to statements in the Federalist Papers, quotations from a variety of other sources often address the same questions that the Federalist Papers consider. In some instances, what the Federalist Papers say may conflict with other materials.

Vikram Amar and Alan Brownstein illustrate this point with their research regarding the role of state legislatures in Presidential elections. ${ }^{162}$ They observe that the Federalist Papers clearly say that state legislatures will play a dominate role in the election of the President. Federalist No. 44 says "the election of the President and Senate will depend, in all cases, on the legislatures of the several states." "163 Federalist No. 45 then says that "without the intervention of the state legislatures, the President of the United States cannot be elected at all. They must in all cases have a great share in his appointment and will, perhaps, in most cases themselves determine it." 164 Amar and Brownstein, however, observe that Madison said at both the Constitutional Convention and at the Virginia State Ratifying Convention that "the people" would choose the President. ${ }^{165}$ In subsequent correspondence, however, Madison expressed still another view, namely, that the states would have popular elections of presidential electors in districts within the state. ${ }^{166}$

\footnotetext{
${ }^{162}$ See Vikram Amar \& Alan Brownstein, Bush v. Gore and Article II: Pressured Judgment Makes Dubious Law, 48 Fed. Law. 27, 31-32 (2001).

${ }^{163}$ The Federalist No. 44, at 307 (James Madison) (Jacob E. Cooke ed. 1961).

164 The Federalist No. 45, at 311 (James Madison) (Jacob E. Cooke ed., 1961).

${ }^{165}$ See Amar \& Brownstein, supra note 133, at 32.

${ }^{166}$ See id.
} 
This example suggests that careful researchers should look for contradictory evidence in sources of the original meaning other than the Federlist Papers because such evidence very well may exist. When other sources contradict the Federalist Papers, it is difficult to know what weight to give the essays. No simple formula says that the notes from the Constitutional Convention trump the Federalist Papers or vice versa. Surely many factors, like the total weight of the evidence on each side, the specificity of the evidence for and against the claim, and lawyerly judgment must play a role. And sometimes researchers must conclude that the Federalist Papers do not provide trustworthy guidance on particular issues. But other documents of course may confirm rather than contradict what the Federalist Papers say.

7. The Federalist Papers provide questionable evidence of the original objective meaning of the Constitution because partisan bias may have influenced the authors' choice of words and phrases.

Some writers, as discussed previously, have cited language in the Federalist Papers to support claims about the original objective meaning of the terms, phrases, and words in the Constitution. They have reasoned (or might reason) that the Federalist Papers provide an extensive and comprehensive corpus of contemporary political language, and that this language will resemble the language used in the Constitution.

Not everyone agrees with this practice. Many years ago, in trying to find the objective meaning of the Constitution, William Winslow Crosskey deliberately consulted only "samples of word-usage and juristic and political discussion . . . from sources not connected with the Constitution." 167 Crosskey explained that he wanted to exclude materials relating to the Constitution, such as the Federalist Papers, because they may "be open to the many natural suspicions that arise from the known or suspected political bias of speakers and writers on the Constitution."168

Crosskey's position is difficult to evaluate. It is conceivable that Hamilton, Madison, and Jay consciously or unconsciously could have modified

\footnotetext{
${ }^{167} 1$ William WinSLOW CROSSKEY, POLITICS AND THE CONSTITUTION IN THE HiSTORY OF THE UNITED STATES 5 (1953).

${ }^{168} I d$. at 5-6.
} 
how they spoke in the Federalist Papers because of their own political goal of obtaining ratification of the Constitution. For example, they might not have used the term "commerce" in a broad way if they thought that it was very important for the term, as used in the Constitution, to have a narrow definition. But that seems unlikely. The three men wrote their essays very quickly, probably without time to adjust their vocabulary sufficiently to conceal to future readers that they were not using language in the ordinary way. And excluding the Federalist Papers and other materials associated with the Constitution, as Crosskey recommends, would be burdensome. The Federalist Papers is an easily accessible historical document that uses the legal and political words and phrases in the Constitution in greater frequency than most other period texts.

Perhaps taking all usages into account, and attempting to account for discrepancies or counteract potential bias, represents the best compromise. In United States v. Lopez, for example, Justice Clarence Thomas looked not only at the Federalist Papers, but also at anti-Federalist writings, ${ }^{169}$ in determining whether the term commerce referred to all gainful activity. This approach seems likely to negate any possible political biases in language usage.

8. The Federalist Papers were not treated as an authoritative exposition of the meaning of the Constitution in the early years of the Republic.

Some authors have argued that the Federalist Papers are not an authoritative exposition of the meaning of the Constitution because government officials often did not follow them in the early years of the Republic. Joseph M. Lynch, for example, has argued that both members of the Federalist Party and their opponent Republican-Democrats ignored what the Federalist Papers said about the necessary and proper clause and other provisions in the Constitution. ${ }^{170}$ He concludes: "It is time for constitutional interpreters to rediscover the forgotten history of the first twelve years of the country and to give no more deference to the constructions espoused in

\footnotetext{
${ }^{169}$ See supra part IV.

${ }^{170}$ Lynch, supra note 111 , at 18.
} 
The Federalist than did the first Federalists or, on occasion, Madison and his fellow Republicans."

This argument may be valid, but it goes mostly to the question of whether courts must follow the original meaning in general. It does little to impeach claims about what the original meaning was based on evidence from the Federalist Papers. Early government officials who decided not to follow Federalist Papers may have reached that decision for reasons other than doubts about whether the Federalist Papers accurately represented the original intent, understanding, or objective meaning of the Constitution. They may have decided, for good reason or not, that they did not want to follow the original meaning of the Constitution. As explained in part II, the question whether officials should follow the original meaning differs from the question of what the original meaning is.

9. The Federalist Papers were not written to provide a definitive interpretation of the Constitution, but instead to address the question of whether the Constitution should be adopted.

A final argument against using the Federalist Papers to show the original meaning of the Constitution is that Hamilton, Madison, and Jay did not intend them to be used for that purpose. As Jack N. Rakove has said, "the overriding imperative was to determine whether the Constitution would be adopted, not to formulate definitive interpretations of its individual clauses." ${ }^{172}$ In addition, as William Eskridge Jr. points out, the authors of the Federalist rested their opinions on many assumptions about the government - such as assumption there would be no gigantic administrative state - that no longer hold true. ${ }^{173}$ Any citation of the Federalist Papers accordingly is a citation out of context.

The extent to which this line of argumentation impeaches claims about the original meaning based on the Federalist Papers is unclear. On one hand, in dashing off essay after essay, Hamilton, Madison, and Jay presumably did not want to bind the nation permanently to what they said.

\footnotetext{
${ }^{171} I d$. at 29.

172 JaCK N. Rakove, ORIginal MEANINGs: Politics and IDEAS IN THE Making OF THE CONSTITUTION 17 (1996).

${ }^{173}$ See Eskridge, supra note 104, at 1310.
} 
Jay himself had been a judge, and Hamilton was an experienced lawyer. They both would have known the risk of issuing opinions on hundreds of complicated legal issues without adequate time for reflection and deliberation and without knowing - as opposed to merely predicting - the operative facts.

The counterargument is simply that Hamilton, Madison, and Jay were expressing their understanding of the Constitution in the best manner possible under the circumstances. While they may have made errors or incomplete analyses, the Federalist Papers still generally may show the original meaning of the Constitution. Again, as mentioned several times, the question whether judges and government officials should follow the original meaning differs from the question of what that original meaning is.

\section{Conclusion}

Thousands of articles and cases have cited the Federalist Papers to support claims about the original meaning of the Constitution. Anyone reading these sources needs to know what the Federalist Papers are, why they might provide evidence of the original meaning of the Constitution, and what weaknesses claims about the original meaning may have if they rest solely on the Federalist Papers. I have attempted here to offer a concise guide. I have sought to provide basic information about the Federalist Papers and the theories for how they may provide evidence of the original meaning. I also have considered nine possible grounds for impeaching claims about the original meaning that rely on the Federalist Papers. Each of these arguments has strengths and weaknesses that researchers should consider. In my own view, the Federalist Papers may not have recorded perfectly what the Framers thought and they may not have influenced many of the ratifiers directly, but scholars can and should see them as a repository of the kinds of arguments that concerned citizens were making and were hearing during the ratification period in 1787-1788. 


\section{Appendix A: Recommended Sources for the Text and Background History of the Federalist Papers}

1. The text of the Federalist Papers as they originally appeared in the New York newspapers can be found in print, on line, and on microfiche. Historian Jacob E. Cooke collected and republished the newspaper version of each essay in The Federalist (Jacob E. Cooke ed., 1961). The Supreme Court regularly cites this definitive work. Cooke carefully indicates with respect to each essay variations in the text and numbering. The Federalist Concordance (Thomas S. Engeman et al. eds., 1980) provides a supplemental index to Cooke's collection. The newspaper version of the essays also is available at the Library of Congress website, at a variety of other free internet sites, and in Westlaw's subscription BICENT database. Readex Microprint Corp.'s Early American Newspaper microform series includes photographic copies of the issues of the New York newspapers that originally published the Federalist Papers.

2. The M'Lean Edition's slightly different text of the Federalist Papers also is available in print and online. Historian Clinton Rossiter reprinted the M'Lean Edition text in The Federalist Papers (Clinton Rossiter ed., 1961). In addition, in 1983, the Legal Classics Library published a photographic reproduction of the original two volumes of the M'Lean Edition. The Constitution Society's free website (www.constitution.org) contains the M'Lean Edition version of the Federalist Papers.

3. James Madison late in life wrote two brief but very informative descriptions of the writings of the Federalist Papers. They can be found in Letter from James Madison to James K. Paulding (July 23, 1818), in 8 The Writings of JAMES MAdison 410 (Galliard Hunt ed., 1908), and James Madison, Memorandum Entitled "The Federalist" (circa 1819), in 4 The Papers of AleXAnder Hamilton 288 (Harold C. Syrett \& Jacob E. Cooke eds., 1962).

4. Jacob E. Cooke and Clinton Rossiter included useful introductions to the Federalist Papers in their collections of the essays. In addition, a thorough description of the writing, publication, and content of the Federalist Papers appears in 13 The Documentary History of the Ratification of the Constitution 486-94 (John P. Kaminski \& Gespare J. Saladino eds., 1981) (commentary no. 201). Extremely detailed information is available in Douglass Adair, The Authorship of the Disputed Federalist Papers, 1 
Wm. \& Mary Quarterly 197 (1944), and Douglass Adair, The Authorship of the Disputed Federalist Papers: Part II, 1 Wm. \& Mary Quarterly 235 (1944). Also helpful is David Epstein, The Federalist, in 5 Encyclopedia of the American Constitution 1013 (Leonard W. Levy \& Kenneth Karst eds., 2000).

\section{Appendix B: Chronology of the Ratification of the Constitution and the Publication of the Federalist Papers}

May 25, 1787 First meeting of the Constitutional Convention

Sept. 27, 1787 Delegates sign the Constitution

Sept. 28, 1787 Congress under the Article of Confederation submits Constitution to the states for ratification.

Oct. 27, 1787 No. 1 General Introduction (Hamilton)

Oct. 31, 1787 No. 2 Concerning Dangers from Foreign Force and Influence (Jay)

Nov. 3, 1787 No. 3 Concerning Dangers from Foreign Force and Influence (continued) (Jay)

Nov. 7, 1787 No. 4 Concerning Dangers from Foreign Force and Influence (continued) (Jay)

Nov. 10, 1787 No. 5 Concerning Dangers from Foreign Force and Influence (continued) (Jay)

Nov. 14, 1787 No. 6 Concerning Dangers from Dissensions Between the States (Hamilton)

Nov. 15, 1787 No. 7 Concerning Dangers from Dissensions Between the States (continued) and Particular Causes Enumerated (Hamilton)

Nov. 20, 1787 No. 8 Consequences of Hostilities Between the States (Hamilton)

Nov. 21, 1787 No. 9 The Utility of the Union as a Safeguard Against Domestic Faction and Insurrection (Hamilton)

Nov. 22, 1787 No. 10 The Utility of the Union as a Safeguard Against Domestic Faction and Insurrection (continued) (Madison)

Nov. 24, 1787 No. 11 The Utility of the Union in Respect to Commercial Relations and a Navy (Hamilton)

Nov. 27, 1787 No. 12 The Utility of the Union In Respect to Revenue (Hamilton) 
Nov. 28, 1787 No. 13 Advantage of the Union in Respect to Economy in Government (Hamilton)

Nov. 30, 1787 No. 14 Objections to the Proposed Constitution From Extent of Territory Answered (Madison)

Dec. 1, 1787 No. 15 Insufficiency of the Present Confederation to Preserve the Union (Hamilton)

Dec. 4, 1787 No. 16 Insufficiency of the Present Confederation to Preserve the Union (continued) (Hamilton)

Dec. 5, 1787 No. 17 Insufficiency of the Present Confederation to Preserve the Union (continued) (Hamilton)

Dec. 7, 1787

No. 18 Insufficiency of the Present Confederation to Preserve the Union (continued) (Madison)

\section{Delaware ratifies.}

Dec. 8, 1787 No. 19 Insufficiency of the Present Confederation to Preserve the Union (continued) (Madison)

Dec. 11,1787

No. 20 Insufficiency of the Present Confederation to Preserve the Union (continued) (Madison)

Dec. 12,1787

No. 21 Other Defects of the Present Confederation (Hamilton)

\section{Pennsylvania ratifies.}

Dec. 14,1787

No. 22 Other Defects of the Present Confederation (continued) (Hamilton)

Dec. 18,1787

No. 23 Necessity of a Government as Energetic as the One Proposed to the Preservation of the Union (Hamilton)

\section{New Jersey ratifies.}

Dec. 19, 1787 No. 24 Powers Necessary to the Common Defense Further Considered (Hamilton)

Dec. 21,1787

No. 25 Powers Necessary to the Common Defense Further Considered (continued) (Hamilton)

Dec. 22, 1787

No. 26 Idea of Restraining the Legislative Authority in Regard to the Common Defense Considered (Hamilton)

Dec. 25,1787

No. 27 Idea of Restraining the Legislative Authority in Regard to the Common Defense Considered (continued) (Hamilton)

Dec. 26,1787

No. 28 Idea of Restraining the Legislative Authority in Regard to the Common Defense Considered (continued) (Hamilton) 
Jan. 2, 1788

Jan. 9, 1788

Dec. 28,1787

Jan. 1, 1788

Jan. 2, 1788

Jan. 2, 1788

Jan. 5, 1788

Jan. 5, 1788

Jan. 8, 1788

Jan. 9, 1788

Jan. 11,1788

Jan. 12,1788

Jan. 16,1788

Jan. 18,1788

Jan. 19, 1788

Jan. 22, 1788

Jan. 23,1788

Jan. 25,1788

Jan. 26, 1788

Jan. 29, 1788
Georgia ratifies.

No. 29 Concerning the Militia (Hamilton)

No. 30 Concerning the General Power of Taxation (Hamilton)

No. 31 Concerning the General Power of Taxation (continued) (Hamilton)

No. 32 Concerning the General Power of Taxation (continued) (Hamilton)

No. 33 Concerning the General Power of Taxation (continued) (Hamilton)

No. 34 Concerning the General Power of Taxation (continued) (Hamilton)

No. 35 Concerning the General Power of Taxation (continued) (Hamilton)

No. 36 Concerning the General Power of Taxation (continued) (Hamilton)

\section{Connecticut ratifies.}

No. 37 Concerning the Difficulties of the Convention in Devising a Proper Form of Government (Madison)

No. 38 The Same Subject Continued, and the Incoherence of the Objections to the New Plan Exposed (Madison)

No. 39 Conformity of the Plan to Republican Principles (Madison)

No. 40 On the Powers of the Convention to Form a Mixed Government Examined and Sustained (Madison)

No. 41 General View of the Powers Conferred by The Constitution (Madison)

No. 42 The Powers Conferred by the Constitution Further Considered (Madison)

No. 43 The Powers Conferred by the Constitution Further Considered (continued) (Madison)

No. 44 Restrictions on the Authority of the Several States (Madison)

No. 45 Alleged Danger From the Powers of the Union to the State Governments Considered (Madison)

No. 46 The Influence of the State and Federal Governments Compared (Madison) 
Jan. 30, 1788

Feb. 1, 1788

Feb. 2, 1788

Feb. 5, 1788

Feb. 6, 1788

Feb. 8, 1788

Feb. 9, 1788

Feb. 12, 1788

Feb. 13, 1788

Feb. 16, 1788

Feb. 19, 1788

Feb. 20, 1788

Feb. 22, 1788

Feb. 23,1788

Feb. 26, 1788

Feb. 27, 1788

Mar. 1, 1788

Mar. 5, 1788
No. 47 The Particular Structure of the New Government and the Distribution of Power Among Its Different Parts (Madison)

No. 48 These Departments Should Not Be So Far Separated as to Have No Constitutional Control Over Each Other (Madison)

No. 49 Method of Guarding Against the Encroachments of Any One Department of Government by Appealing to the People Through a Convention (Madison)

No. 50 Periodical Appeals to the People Considered (Madison)

No. 51 The Structure of the Government Must Furnish the Proper Checks and Balances Between the Different Departments (Madison)

\section{Massachusetts ratifies.}

No. 52 The House of Representatives (Madison)

No. 53 The House of Representatives (continued) (Madison)

No. 54 Apportionment of Members of the House of Representatives Among the States (Madison)

No. 55 The Total Number of the House of Representatives (Madison)

No. 56 The Total Number of the House of Representatives (continued) (Madison)

No. 57 The Alleged Tendency of the New Plan to Elevate the Few at the Expense of the Many Considered in Connection with Representation (Madison)

No. 58 Objection That The Number of Members Will Not Be Augmented as the Progress of Population Demands Considered (Madison)

No. 59 Concerning the Power of Congress to Regulate the Election of Members (Hamilton)

No. 60 Concerning the Power of Congress to Regulate the Election of Members (continued) (Hamilton)

No. 61 Concerning the Power of Congress to Regulate the Election of Members (continued) (Hamilton)

No. 62 The Senate (Madison)

No. 63 The Senate (continued) (Madison)

No. 64 The Powers of the Senate (Jay) 
Mar. 7, 1788 No. 65 The Powers of the Senate (continued) (Hamilton)

Mar. 8, 1788 No. 66 Objections to the Power of the Senate To Set as a Court for Impeachments Further Considered (Hamilton)

Mar. 11, 1788 No. 67 The Executive Department (Hamilton)

Mar. 12, 1788 No. 68 The Mode of Electing the President (Hamilton)

Mar. 14, 1788 No. 69 The Real Character of the Executive (Hamilton)

Mar. 15, 1788 No. 70 The Executive Department Further Considered (Hamilton)

Mar. 18, 1788 No. 71 The Duration in Office of the Executive (Hamilton)

Mar. 19, 1788 No. 72 The Same Subject Continued, and Re-Eligibility of the Executive Considered (Hamilton)

Mar. 21, 1788

No. 73 The Provision For The Support of the Executive, and the Veto Power (Hamilton)

Mar. 25, 1788

No. 74 The Command of the Military and Naval Forces, and the Pardoning Power of the Executive (Hamilton)

Mar. 26, 1788

No. 75 The Treaty-Making Power of the Executive (Hamilton)

Apr. 1, 1788

No. 76 The Appointing Power of the Executive (Hamilton)

Apr. 2, 1788

No. 77 The Appointing Power Continued and Other Powers of the Executive Considered (Hamilton)

Apr. 28, 1788 Maryland ratifies.

May 23, 1788 South Carolina ratifies.

May 28, 1788 The M'Lean edition is published, containing these 8 new essays:

No. 78 The Judiciary Department (Hamilton)

No. 79 The Judiciary Continued (Hamilton)

No. 80 The Powers of the Judiciary (Hamilton)

No. 81 The Judiciary Continued, and the Distribution of the Judicial Authority (Hamilton)

No. 82 The Judiciary Continued (Hamilton)

No. 83 The Judiciary Continued in Relation to Trial by Jury (Hamilton)

No. 84 Certain General and Miscellaneous Objections to the Constitution Considered and Answered (Hamilton)

No. 85 Concluding Remarks (Hamilton)

June 2, 1788 New Hampshire ratifies. 
The Constitution is established among the ratifying states because nine states have ratified it.

June 25, 1788 Virginia ratifies.

July 26, 1788 New York ratifies.

March 4, 1789 The Constitution goes into effect.

Nov. 21, 1789 North Carolina ratifies.

May. 29, 1789 Rhode Island ratifies. 